\title{
Postsynaptic Calcium Influx at Single Synaptic Contacts between Pyramidal Neurons and Bitufted Interneurons in Layer 2/3 of Rat Neocortex Is Enhanced by Backpropagating Action Potentials
}

\author{
Katharina M. M. Kaiser, ${ }^{1}$ Joachim Lübke, ${ }^{2 \star}$ Yuri Zilberter, ${ }^{1,3 *}$ and Bert Sakmann ${ }^{1}$ \\ ${ }^{1}$ Abteilung Zellphysiologie, Max-Planck-Institut für Medizinische Forschung, D-69120 Heidelberg, Germany, ${ }^{2}$ Anatomisches Institut der Universität

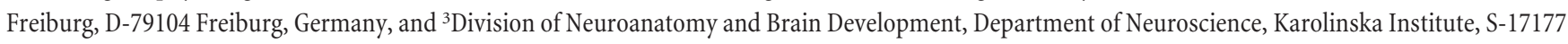 \\ Stockholm, Sweden
}

Pyramidal neurons in layer 2/3 (L2/3) of the rat somatosensory cortex excite somatostatin-positive inhibitory bitufted interneurons located in the same cortical layer via glutamatergic synapses. A rise in volume-averaged dendritic $\left[\mathrm{Ca}^{2+}\right]_{\mathrm{i}}$ evoked by backpropagating action potentials (APs) reduces glutamatergic excitation via a retrograde signal, presumably dendritic GABA. To measure the rise in local $\left[\mathrm{Ca}^{2+}\right]_{\mathrm{i}}$ at synaptic contacts during suprathreshold excitation, we identified single synaptic contacts in the acute slice preparation in pairs of pyramidal and bitufted cells each loaded with a $\mathrm{Ca}^{2+}$ indicator dye. Repetitive APs (10-15 APs at $\left.50 \mathrm{~Hz}\right)$ evoked in a L2/3 pyramidal neuron gave rise to facilitating unitary EPSPs in the bitufted cell. Subthreshold EPSPs evoked a transient rise in $\left[\mathrm{Ca}^{2+}\right]_{\mathrm{i}}$ of $80-250 \mathrm{nM} \mathrm{peak}$ amplitude at the postsynaptic dendritic site. The local postsynaptic $\left[\mathrm{Ca}^{2+}\right]_{\mathrm{i}}$ transient was restricted to $\sim 10 \mu \mathrm{m}$ of dendritic length, lasted for $\sim 200 \mathrm{msec}$, and was mediated predominantly by NMDA receptor channels. When EPSPs were suprathreshold, the evoked AP backpropagated into the apical and basal dendritic arbor and increased the local $\left[\mathrm{Ca}^{2+}\right]_{\mathrm{i}}$ transient at active contacts by approximately twofold, with a peak amplitude reaching $130-450 \mathrm{~nm}$. This value is in the range of the half-maximal dendritic $\left[\mathrm{Ca}^{2+}\right]_{\mathrm{i}}$, evoking retrograde inhibition of glutamate release from boutons of pyramids. The localized enhancement of dendritic $\mathrm{Ca}^{2+}$ influx at synaptic contacts by synaptically evoked backpropagating APs could represent one mechanism by which a retrograde signal can limit the excitation of bitufted interneurons by $\mathrm{L} 2 / 3$ pyramids when these are repetitively active.

Key words: interneuron; neocortex; unitary synaptic stimulation; synaptic contact; calcium transient; calcium diffusion

\section{Introduction}

Inhibitory GABAergic interneurons constitute a relatively small but heterogeneous population $(\cong 10 \%)$ in the neocortex (Jones and Peters, 1984). These interneurons possess extensive axonal arborization (Somogyi et al., 1998) and control excitability of the cortical circuitry by feedforward and feedback inhibition (Cobb et al., 1995). One subclass of interneurons, referred to as "bitufted," somatostatin-positive interneurons (Kawaguchi, 1995; Reyes et al., 1998; Cauli et al., 2000) have their somata located mostly in supragranular layer $2 / 3$ (L2/3). They are characterized by an elongated, vertically oriented bitufted dendritic arbor extending through a cortical column (Kaiser et al., 2001).

\footnotetext{
Received Aug. 15, 2003; revised Nov. 27, 2003; accepted Dec. 1, 2003.

We thank Dr. T. Nevian for help with two-photon microscopy and preparation of Figure 5 and Randy Bruno for help in preparing this manuscript.

*J.L. and Y.Z. contributed equally to this article.

Correspondence should be addressed to Dr. Katharina Kaiser, Abteilung Zellphysiologie, Max-Planck-Institut für Medizinische Forschung, Jahnstrasse 29, D-69120 Heidelberg, Germany. E-mail: kaiser@mpimf-heidelberg. mpg.de.

J. Lübke's present address: Institut für Medizin, Forschungszentrum Jülich GmbH, D-52425 Jülich, Germany. D01:10.1523/JNEUROSCI.2852-03.2004

Copyright $\odot 2004$ Society for Neuroscience $\quad$ 0270-6474/04/241319-11\$15.00/0
}

Their axonal arbors also project throughout L1-L6, and, in addition, they have extensive horizontal axon collaterals in supragranular layers. The horizontal and vertical spread of their axon arbors suggests that bitufted cells can control the excitation within a cortical column and, possibly in the supragranular layers, also between columns (Kaiser et al., 2001).

The efficacy of synaptic connections between pyramids and bitufted cells is low (Reyes et al., 1998), but EPSPs strongly facilitate during repetitive $(10 \mathrm{~Hz})$ pyramidal cell activity (Markram et al., 1998; Reyes et al., 1998; Rozov et al., 2001), suggesting that cortical inhibition via bitufted interneurons operates predominantly during repetitive stimulation of the afferent sensory pathways. Such repetitive activity may occur in the somatosensory cortex, for example, during exploratory "whisking" of the vibrissas of the rodent's muzzle. A train of action potentials (APs) in L2/3 pyramidal cells can evoke summated EPSPs that are large enough to initiate one or several APs in bitufted cells. APs in bitufted cells backpropagate into the dendritic arbors and evoke a transient rise in calcium concentration $\left(\left[\mathrm{Ca}^{2+}\right]_{\mathrm{i}}\right.$ ) (Kaiser et al., 2001). These dendritic $\left[\mathrm{Ca}^{2+}\right]_{\mathrm{i}}$ transients decrease the efficacy of synaptic transmission of the pyramid-to-bitufted cell connec- 
tions with a half-maximal effect when the volume-averaged rise in dendritic $\left[\mathrm{Ca}^{2+}\right]_{\mathrm{i}}$ reaches $\sim 250 \mathrm{nM}$ (Zilberter et al., 1999).

To delineate the origin, size, and time course of $\mathrm{Ca}^{2+}$ influx and its dendritic profile at individual synaptic contacts in pyramidal-to-bitufted connections we measured postsynaptic dendritic $\left[\mathrm{Ca}^{2+}\right]_{\mathrm{i}}$ transients evoked by subthreshold or suprathreshold EPSPs at morphologically identified synaptic contacts. We observed a localized increase of dendritic $\left[\mathrm{Ca}^{2+}\right]_{\mathrm{i}}$ during summated EPSPs, which was enhanced approximately twofold when EPSPs evoked an AP. The rise in $\left[\mathrm{Ca}^{2+}\right]_{i}$ at active synaptic contacts was in the range to trigger short-term depression of synaptic efficacy locally via retrograde messengers released from the dendrite (Zilberter et al., 1999).

\section{Materials and Methods}

Slice preparation. All animal procedures were performed according to the animal welfare guidelines of the Max Planck Society. Brain slices ( $300 \mu \mathrm{m}$ thick) were prepared from the somatosensory cortex of postnatal day 13 (P13) to P15 Wistar rats as described previously (Markram et al., 1997). Bitufted and pyramidal neurons in L2/3 were identified by infrared (IR)differential interference contrast videomicroscopy and readily selected according to their firing pattern on prolonged current injection (Reyes et al., 1998; Kaiser et al., 2001) and by the fact that on repetitive APs in pyramidal cells the unitary EPSPs in the target cell facilitated in amplitude.

Electrophysiology. Membrane voltage was recorded with pipettes containing the following (in $\mathrm{mm}$ ): $100 \mathrm{~K}$-gluconate, $20 \mathrm{KCl}, 4 \mathrm{ATP}-\mathrm{Mg}, 10$

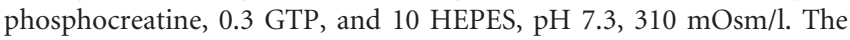
extracellular solution contained the following (in $\mathrm{mm}$ ): $125 \mathrm{NaCl}, 2.5$ $\mathrm{KCl}, 25$ glucose, $25 \mathrm{NaHCO}_{3}, 1.25 \mathrm{NaH}_{2} \mathrm{PO}_{4}, 2 \mathrm{CaCl}_{2}$, and $1 \mathrm{MgCl}_{2}$. Experiments were made at $34^{\circ} \mathrm{C}$, except experiments using two-photon excitation, which were made at room temperature $\left(\sim 24^{\circ} \mathrm{C}\right)$. Voltages were recorded using Axoclamp-2B amplifiers (Axon Instruments, Foster City, CA). For the voltage-clamp experiments we used an Axopatch200A amplifier (Axon Instruments).

Morphology. During recording, presynaptic and postsynaptic neurons were filled with biocytin $(2 \mathrm{mg} / \mathrm{ml})$ for subsequent light- and electronmicroscopic (EM) analysis. Slices were fixed and processed according to a protocol described previously (Lübke et al., 2000). Neurons were traced with the Neurolucida program using a $60 \times$ objective lens. The number and distribution of putative synaptic contacts were identified under light microscopy using the following criteria: presynaptic axon and postsynaptic dendrite were in close apposition and in the same plane of focus. In one selected pair the light-microscopically identified contacts were confirmed by EM.

Dendritic $\mathrm{Ca}^{2+}$ fluorescence imaging. Bitufted and pyramidal neurons were filled via somatic recording pipettes containing $250 \mu \mathrm{m}$ fura- 2 and $400 \mu \mathrm{M}$ mag-fura-2, respectively, unless stated otherwise (all dyes are from Molecular Probes, Eugene, OR) for at least 10 min before recording. Fluorescence was imaged via a $60 \times$ Olympus (Tokyo, Japan) immersion objective lens mounted on an upright microscope (Axioskop FS2; Zeiss, Jena, Germany). A monochromatic light source was used for fluorescence excitation (T.I.L.L., Munich, Germany). A back-illuminated frame transfer CCD camera (Princeton Instruments, Trenton, NJ) was used to acquire ratioed signals $(356 / 380 \mathrm{~nm})$ simultaneously from up to nine regions of interest at a frequency of $100 \mathrm{~Hz}$. Traces were converted to $\left[\mathrm{Ca}^{2+}\right]_{\mathrm{i}}$ using the standard conversion formula (Grynkiewicz et al., 1985) (see Eq.1) and smoothed using a binomial filter, if not noted otherwise. Peak $\left[\mathrm{Ca}^{2+}\right]_{\mathrm{i}}$ amplitudes were obtained from fitting the decay of $\left[\mathrm{Ca}^{2+}\right]_{\mathrm{i}}$ transients with a single exponential.

Overlap of fura-2 and mag-fura-2 fluorescence. As the spectra of fura-2 and mag-fura- 2 overlap, the detected fluorescence signal at axodendritic intersections is a sum of fluorescence contributed by the postsynaptic dendrite and by the presynaptic axon loaded with fura- 2 and mag-fura- 2 , respectively. These fluorescence intensities could not be corrected for the additional fluorescence contributed by the presynaptic axon, which re- sults in an error of the estimate of $\mathrm{Ca}^{2+}$ concentrations $\left(\left[\mathrm{Ca}^{2+}\right]_{\mathrm{i}}\right)$ when fluorescence signals were converted.

Assuming background-subtracted fluorescence signals, the measured fluorescence ratio at the synaptic contact

$$
R_{\text {measured }}=\frac{F_{356}^{\text {fura-2 }}+F_{356}^{\text {mag-fura-2 }}}{F_{380}^{\text {fura-2 }}+F_{380}^{\text {mag-fura-2 }}}
$$

overestimates the actual ratio

$$
R=\frac{F_{356}^{\text {fura- } 2}}{F_{380}^{\text {fura- } 2}}
$$

by

$$
\Delta R=R \cdot \frac{k_{380}-k_{356}}{1+k_{380}}
$$

with the contribution factors of mag-fura-2 to the fluorescence

$$
k_{356}=\frac{F_{356}^{\text {mag-fura-2 }}}{F_{356}^{\text {fura-2 }}}
$$

and

$$
k_{380}=\frac{F_{380}^{\text {mag-fura-2 }}}{F_{380}^{\text {fura-2 }}} .
$$

In one intersection we estimated the fluorescence change contributed by the presynaptic bouton by measuring the fluorescence intensities of an axodendritic intersection and of an adjacent axonal segment at the two wavelengths (356 and $380 \mathrm{~nm}$ ) used for ratiometric $\left[\mathrm{Ca}^{2+}\right]_{\mathrm{i}}$ measurements. Assuming that the axon covers one-third (upper limit) of the region of the axodendritic intersection, its contribution to the fluorescence at the $\mathrm{Ca}^{2+}$-dependent wavelength was $k_{356}=27 \%$ and $k_{380}=$ $17 \%$ for the $\mathrm{Ca}^{2+}$-independent wavelength. Thus, the measured fluorescence ratio at the synaptic contact was overestimated by $\Delta R=8 \%$.

According to the ratio- $\left[\mathrm{Ca}^{2+}\right]_{\mathrm{i}}$ conversion formula (Grynkiewicz et al., 1985)

$$
\left[\mathrm{Ca}^{2+}\right]_{\mathrm{i}}=K_{\mathrm{D}} \cdot \frac{R-R_{\min }}{R_{\max }-R}
$$

this results in an error of $\mathrm{Ca}^{2+}$ signals $\Delta\left[\mathrm{Ca}^{2+}\right]_{\mathrm{i}}$, which is proportional to the absolute $\mathrm{Ca}^{2+}$ signal multiplied by the error of the measured ratio $\Delta R$

$$
\Delta\left[\mathrm{Ca}^{2+}\right]_{\mathrm{i}}=\frac{1}{R_{\max }-R}\left(K_{\mathrm{D}}+\left[\mathrm{Ca}^{2+}\right]_{\mathrm{i}}\right) \cdot \Delta \mathrm{R}
$$

Presynaptic contribution to $\mathrm{Ca}^{2+}$ fluorescence changes. To estimate the presynaptic contribution to the recorded fluorescence changes, we filled five L2/3 pyramidal neurons with $400 \mu \mathrm{M}$ mag-fura- $2\left(K_{\mathrm{D}}=25 \mu \mathrm{M}\right)$ and scanned fluorescence changes, which were evoked by trains of $10-15$ APs at $50 \mathrm{~Hz}$, at 93 regions on the main axon and 24 regions on axon collaterals. The regions were located between 4 and $174 \mu \mathrm{m}$ away from the soma. All neurons showed the largest fluorescence changes $\Delta F_{\text {mag-fura-2 }} /$ $F_{\text {mag-fura-2 }}$ of $1-3 \%$ on the initial axon segments. $\Delta F_{\text {mag-fura-2 } 2} / F_{\text {mag-fura-2 }}$ dropped within $25-50 \mu \mathrm{m}$ to values below $1 \%$, on average $0.5 \pm 0.1 \%$ ( $n=5$ neurons). Collaterals showed slightly larger $\Delta F_{\text {mag-fura- } 2} / F_{\text {mag- }}$ fura-2 changes ( $0.7 \pm 0.4 \% ; n=24$ regions) probably because of a different surface/volume ratio. For four neurons, we found regions without changes in fluorescence on the main axon and collaterals. Interestingly, three regions on collaterals had fluorescence changes similar to those in the initial axon segment. These regions probably covered boutons. 

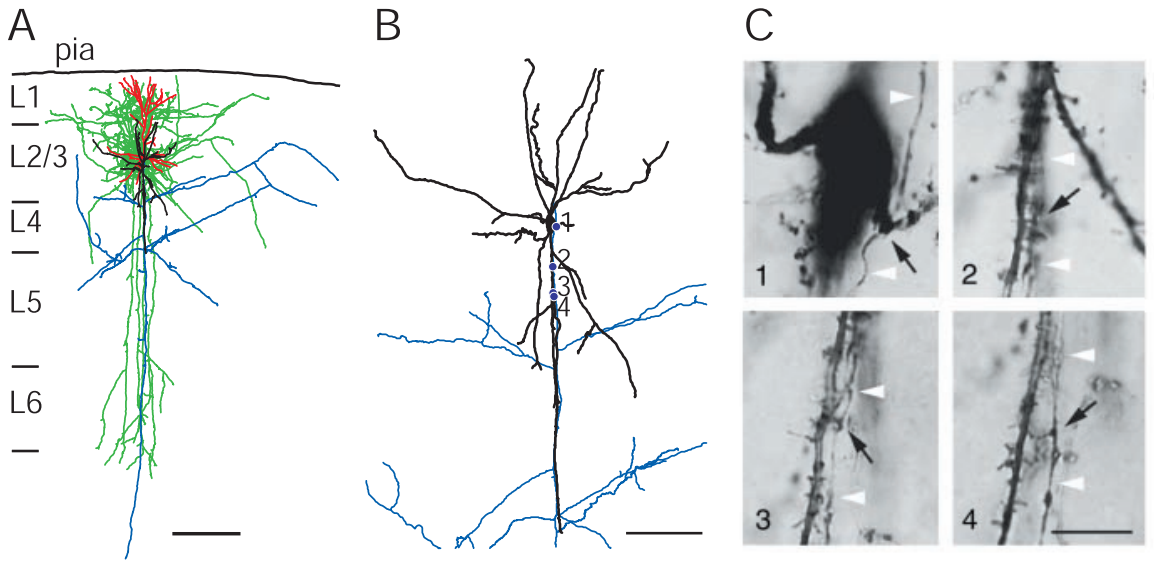

Figure 1. Neurolucida reconstruction and identification of synaptic contacts formed between L2/3 pyramidal and bitufted neuron. $A$, The somatodendritic domain of the presynaptic pyramidal neuron of a pyramid-to-bitufted cell pair is shown in red and the axon arbor in blue. The main axon descends toward the white matter while giving rise to several long horizontal collaterals in L2/3-L5. The soma and dendritic arbor of the postsynaptic bitufted interneuron innervated by the pyramidal neuron are drawn in black and the axon arbor in green. Note the two axonal domains of the bitufted interneuron: a dense projection confined to supragranular L2/3 and L1 and a vertically oriented, descending projection spanning L2/3-L6. Scale bar, $300 \mu \mathrm{m}$. B, Superposition of part of the pyramidal cell axonal arbor (blue) and the somatodendritic domain of the bitufted interneuron (black) at higher magnification. Blue dots indicate four putative synaptic contacts established by axon collaterals of the pyramidal cell on bitufted neuron dendrites. Note that all synaptic contacts in this cell pair were established within $100 \mu \mathrm{m}$ from the soma of the bitufted interneuron. Scale bar, $100 \mu \mathrm{m}$. C, Photomicrographs of putative synaptic contacts, numbers correspond to those in B. Synaptic contacts were established on dendritic shafts $(1,2)$ or dendritic spines $(3,4)$, but not on the soma. Black arrows point to the putative synaptic contacts identified light microscopically; white arrowheads indicate the en passant axon. Scale bar, $10 \mu \mathrm{m}$.

The recorded fluorescence change at an identified synaptic contact is the sum of changes contributed by fura- 2 and mag-fura-2, i.e.,

$$
\frac{\Delta F}{F}=\frac{\Delta F_{\text {fura-2 }}+\Delta F_{\text {mag-fura-2 }}}{F_{\text {fura-2 }}+F_{\text {mag-fura-2 }}} .
$$

Thus, the fluorescence change of fura- 2 relative to the absolute fluorescence is

$$
\frac{\Delta F_{\text {fura-2 }}}{F}=\frac{\Delta F}{F}-\frac{\Delta F_{\text {mag-fura-2 }}}{F_{\text {mag-fura-2 }}} \cdot \frac{F_{\text {mag-fura-2 }}}{F},
$$

with typically $\Delta F / F=0.03-0.078$ for recorded fluorescence changes evoked by subthreshold and suprathreshold EPSPs, $\Delta F_{\text {mag-fura-2 }} /$ $F_{\text {mag-fura-2 }}=0.005-0.01$ (see above) and $F_{\text {mag-fura-2 }} / F=0.1-0.3$ for the contribution of mag-fura- 2 to the total fluorescence. This leads to a minimal postsynaptic contribution $\Delta F_{\text {fura- } 2} / F$ of $90 \%$ to the total change, when the recorded fluorescence change is small $(\Delta F / F=0.03)$ in combination with a large presynaptic change $\left(\Delta F_{\text {mag-fura-2 }} / F_{\text {mag-fura-2 }}=0.01\right)$ and high presynaptic intensity at the synaptic contact $\left(F_{\text {mag-fura- } 2} / F=\right.$ 0.3 ). In other words, the maximal presynaptic contribution is $10 \%$. Typical values for the presynaptic contribution were calculated to be between 1 and $4 \%$ for the main axon and between 4 and $7 \%$ for boutons on collaterals.

$\mathrm{Ca}^{2+}$ fluorescence imaging using two-photon excitation. To record presynaptic and postsynaptic $\left[\mathrm{Ca}^{2+}\right]_{\mathrm{i}}$ transients simultaneously during unitary synaptic stimulation we used two-photon excitation microscopy. Pyramid-to-bitufted cell pairs were loaded with the two different $\mathrm{Ca}^{2+}$ sensitive dyes rhod-2 $\left(K_{\mathrm{D}}=570 \mathrm{nM}\right)$ and Oregon green-488 BAPTA-1 $(\mathrm{OGB}-1)\left(K_{\mathrm{D}}=170 \mathrm{~nm}\right)$. Pyramidal neurons were filled with $275 \mu \mathrm{M}$ rhod-2 and bitufted interneurons with $200 \mu \mathrm{M}$ OGB-1 for at least $15 \mathrm{~min}$ before imaging began. The emission spectra of the two dyes were separated by using an IR block filter at $700 \mathrm{~nm}$, a dichroic mirror at $560 \mathrm{~nm}$, and bandpass filters at 525/50 and 610/75 $\mathrm{nm}$.

The two-photon setup was assembled from a Scan-Microscope (Leica, Nussloch, Germany) fitted with a $40 \times$ objective lens. $\Delta F / F$ transients were recorded in the line-scan mode with a time resolution of $250 \mathrm{~Hz}$. The emission light from OGB-1 was averaged from two photomultiplier tubes (PMTs), one at the epifluorescence and one at the condenser out- put port. The emission of rhod-2 was recorded at the epifluorescence port with a third PMT.

\section{Results \\ Morphology of connections between pyramidal cells and bitufted interneurons in $\mathrm{L} 2 / 3$}

The morphology of presynaptic pyramidal cells, which were reconstructed from paired recordings (Fig. $1 A$ ) was characterized by a main apical dendrite that formed a tuft comparable with pyramids described previously (DeFelipe and Farinas, 1992; Schröder and Luhmann, 1997; Lübke et al., 2003). The main axon always originated from the soma opposite the apical trunk and gave rise to numerous, often very long (up to 2-2.5 $\mathrm{mm}$ ) tangential collaterals predominantly in L2/3 and L5 (Fig. $1 A)$. Ascending collaterals could terminate in L1; descending collaterals projected toward L5, L6, and the white matter. Synaptic contacts with bitufted interneurons were mainly established by the descending axon collaterals.

The dendritic morphology of bitufted neurons, which were postsynaptic to pyramidal cells, was characterized by a predominantly vertical dendritic arborization within L2/3 extending to L5 (Fig. $1 A$ ). Dendrites of bitufted interneurons were covered with spines; however, their density was lower compared with pyramidal cells in L2/3 and was variable between individual neurons. The axonal projections of bitufted neurons were also primarily columnar, with two characteristic axonal arbors (Fig. $1 A$ ). One dense, basket-like axonal domain was restricted to $\mathrm{L} 1, \mathrm{~L} 2 / 3$, and upper $\mathrm{L} 4$, with a high degree of collateralization, extending horizontally as far as $1 \mathrm{~mm}$. The second prominent axonal domain was extending vertically into L4 and L5 with single, long collaterals, which projected to L6. Both axonal domains were confined primarily to the dimensions of a cortical column; however, the supragranular domain extended into adjacent columns (Kaiser et al., 2001). Frequently, the descending axon collaterals of pyramidal cells were oriented in parallel with the vertically oriented basal dendrites of bitufted cells, forming several putative synaptic contacts (Fig. $1 B, C$ ). The number of putative synaptic contacts per cell pair was $3.9 \pm 2.8$ (mean $\pm \mathrm{SD} ; n=18$ pairs; range, 1-14 contacts). The majority of synapses was located within $200 \mu \mathrm{m}$ distance from the soma, but some were located up to $600 \mu \mathrm{m}$ away (data not shown).

\section{Ultrastructure of synaptic contacts}

Serial ultrathin sectioning was performed throughout the somatodendritic region of the presynaptic and postsynaptic neuron of one cell pair to identify the type of single contacts. In the cell pair shown in Figure $2 A$, two synaptic contacts (marked b1 and b2) on dendritic shafts were identified on secondary dendrites of the bitufted interneuron. They were located in L2/3 (b1) and L4 (b2). Both contacts were established by a single axon collateral of the pyramidal cell on a dendritic shaft of the bitufted neuron and were confirmed as boutons at the EM level. The ultrastructure of one bouton (b1) is shown in Figure $2 C$. 


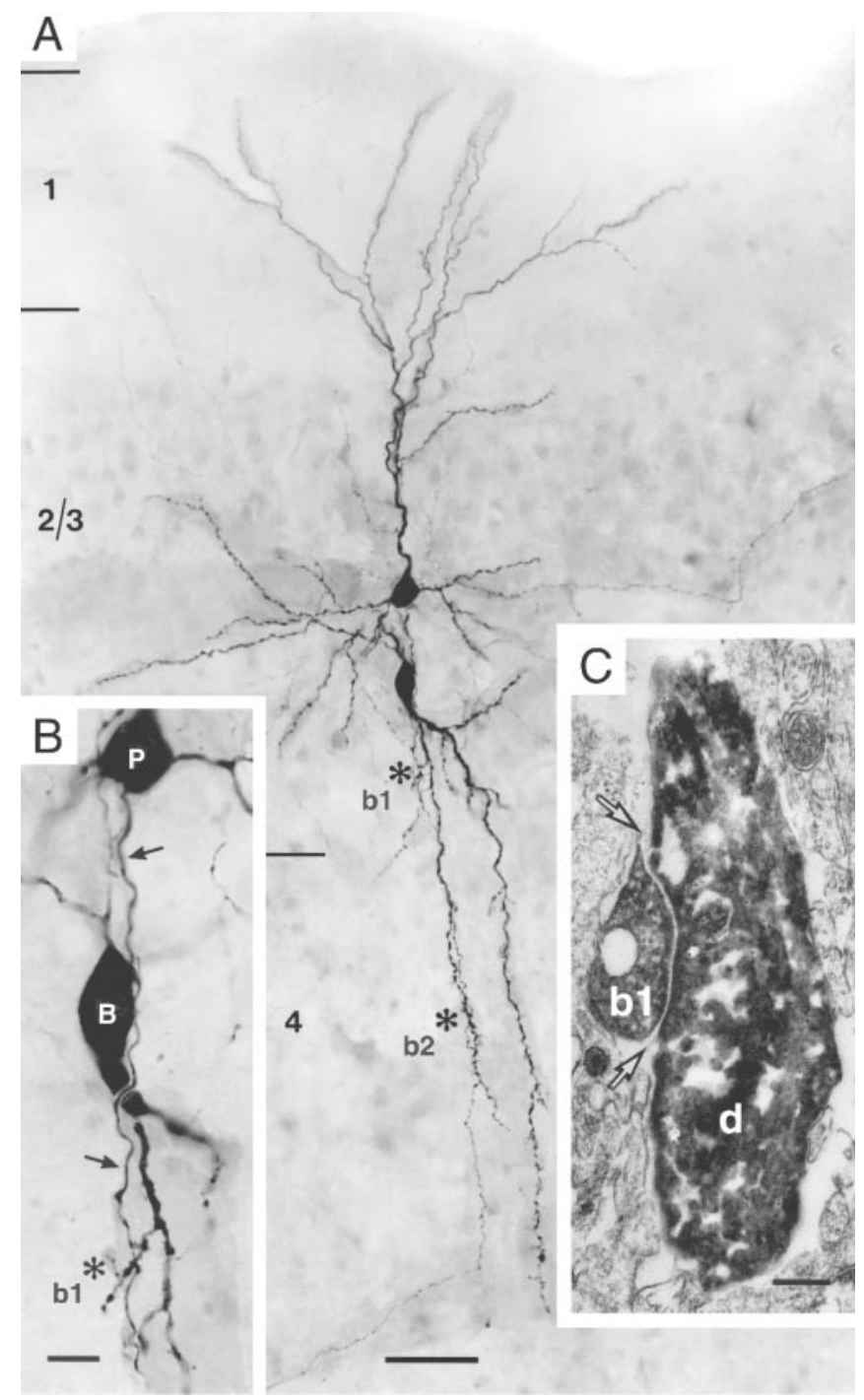

Figure 2. Morphology of pyramidal-to-bitufted cell connection in L2/3. A, Low-power photomontage of the somatodendritic morphology of the presynaptic pyramidal cell (upper cell body) and the postsynaptic interneuron (lower cell body). Asterisks (marked as b1 and b2) indicate two, putative synaptic contacts identified on light microscopy between pyramidal cell axon and dendrites of the bitufted cell. Scale bar, $50 \mu \mathrm{m}$. B, Higher magnification of the somatodendritic region showing synaptic contact b1 (asterisk). Arrows mark the descending axon of the pyramidal neuron $(P)$ that established a synaptic contact on a secondary dendrite of the bitufted interneuron (B). Scale bar, $10 \mu \mathrm{m}$. C, Electron microscopic image of synaptic contact (b1) established on the dendritic shaft (d) of the bitufted interneuron as shown on light microscopy in $B$. Arrows point to the synaptic cleft. Scale bar, $0.2 \mu \mathrm{m}$.

\section{Dendritic $\mathrm{Ca}^{2+}$ influx evoked by subthreshold and suprathreshold EPSPs}

In pairs of pyramidal neurons innervating bitufted interneurons, a train of 10-15 APs (at $50 \mathrm{~Hz}$ ), initiated by somatic current injection into the pyramidal cell, evoked a train of unitary EPSPs (Fig. 3A). These summated EPSPs became suprathreshold in approximately one-fourth of the 438 trials recorded from 16 cell pairs (Fig. 3A, right), but remained subthreshold (Fig. 3A, left) in the other trials. Suprathreshold EPSPs (EPSPs-APs) evoked a transient rise in $\left[\mathrm{Ca}^{2+}\right]_{\mathrm{i}}$ in the dendrites that was detected when bitufted neurons were loaded with the $\mathrm{Ca}^{2+}$ indicator fura-2 (250 $\mu \mathrm{M})$. Dendritic $\left[\mathrm{Ca}^{2+}\right]_{\mathrm{i}}$ transients evoked by suprathreshold EPSPs had a peak amplitude ranging from a few tens to $\sim 100 \mathrm{nM}$ and were detectable along the entire length of the dendrites (Fig.
$3 B)$. The mean decay time constant of the $\left[\mathrm{Ca}^{2+}\right]_{\mathrm{i}}$ transients was $638 \pm 246 \mathrm{msec}(n=111$ dendritic regions from 25 neurons). The peak $\left[\mathrm{Ca}^{2+}\right]_{\mathrm{i}}$ amplitudes are 2.5 -fold larger, and the decay time constants three times shorter, when corrected for the $\mathrm{Ca}^{2+}$ binding ratio of the added fura-2 (Kaiser et al., 2001). Scanning different sites along the dendrites for $\left[\mathrm{Ca}^{2+}\right]_{\mathrm{i}}$ transients during subthreshold EPSPs, however, revealed two sorts of behavior (Fig. 3C). At most dendritic sites, subthreshold EPSPs evoked no detectable $\mathrm{Ca}^{2+}$ signal (Fig. 3C, region 2, top), whereas suprathreshold EPSPs always gave rise to a $\left[\mathrm{Ca}^{2+}\right]_{\mathrm{i}}$ transient (Fig. $3 \mathrm{C}$, region 2, bottom). In a small fraction of dendritic regions, both subthreshold and suprathreshold EPSPs evoked $\left[\mathrm{Ca}^{2+}\right]_{i}$ transients, the latter having a larger peak amplitude (Fig. 3C, region 1 ). This difference could be caused by functional synaptic contacts located in the vicinity of a recording site that would mediate $\mathrm{Ca}^{2+}$ influx through both glutamate- and voltage-activated channels. Application of APV $(100 \mu \mathrm{M})$ blocked the $\mathrm{Ca}^{2+}$ signal during subthreshold stimulation (data not shown), supporting this view.

\section{Identification of individual synaptic contacts by $\mathrm{Ca}^{2+}$ fluorescence imaging}

To delineate the size, spatial extent, and relative contribution of glutamate- and voltage-activated channels to the dendritic $\mathrm{Ca}^{2+}$ influx at synaptic contacts, we measured $\left[\mathrm{Ca}^{2+}\right]_{\mathrm{i}}$ transients at individual identified contacts. Pyramidal cells were loaded with mag-fura-2 $(400 \mu \mathrm{M})$ to visualize axon collaterals. Bitufted neurons were filled with fura-2 $(250 \mu \mathrm{M})$ for recording dendritic $\left[\mathrm{Ca}^{2+}\right]_{\mathrm{i}}$ transients. Loading the pyramidal cell with mag-fura-2 did not reduce synaptic efficacy because summated EPSPs in bitufted neurons could become suprathreshold with approximately the same probability as in controls. Intersections between pyramidal axon collaterals and dendrites of a bitufted neuron were identified in the same focal plane (Fig. $4 A, B$ ). Some of these axodendritic crossings showed a postsynaptic $\mathrm{Ca}^{2+}$ signal even when the response remained subthreshold (Fig. 4C, top trace), suggesting that these sites were active synaptic contacts. All putative synaptic contacts in different cell pairs were located relatively close to the soma of the bitufted interneuron, on average at a distance of $31 \pm 16 \mu \mathrm{m}(n=42$; range, $6-73 \mu \mathrm{m})$. One active synaptic contact was selected for subsequent EM analysis to verify that the "hot spots" of dendritic $\mathrm{Ca}^{2+}$ influx were synaptic contacts. At the dendritic site, where $\left[\mathrm{Ca}^{2+}\right]_{\mathrm{i}}$ transients evoked by subthreshold EPSPs were detected, a contact was established between a single axon collateral of the pyramidal neuron and a dendritic shaft of the bitufted interneuron (Fig. 3C).

An example of a spatial profile of $\left[\mathrm{Ca}^{2+}\right]_{\mathrm{i}}$ transients evoked by EPSPs at a synaptic contact is illustrated in Figure $4 C$. The largest peak $\left[\mathrm{Ca}^{2+}\right]_{\mathrm{i}}$ amplitude was measured at the axodendritic intersection. The peak decreased within a few micrometers along the adjacent dendritic segments. In the pyramidal cell axon collateral in the vicinity of the synaptic contact, no $\mathrm{Ca}^{2+}$ signals were detected (data not shown). When EPSPs were suprathreshold, the $\left[\mathrm{Ca}^{2+}\right]_{\mathrm{i}}$ transients at the synaptic contacts were approximately twofold higher than those evoked by subthreshold EPSPs (Fig. $4 D)$. This suggests that the $\left[\mathrm{Ca}^{2+}\right]_{\mathrm{i}}$ transient is mostly of postsynaptic origin.

\section{Variability of $\left[\mathrm{Ca}^{2+}\right]_{\mathrm{i}}$ transients}

An additional indication that the measured $\left[\mathrm{Ca}^{2+}\right]_{\mathrm{i}}$ transients are predominantly of postsynaptic origin is their variability. Synaptic transmission between L2/3 pyramidal and bitufted neurons has a high failure rate (Reyes et al., 1998; Zilberter et al., 1999; Rozov et 
A
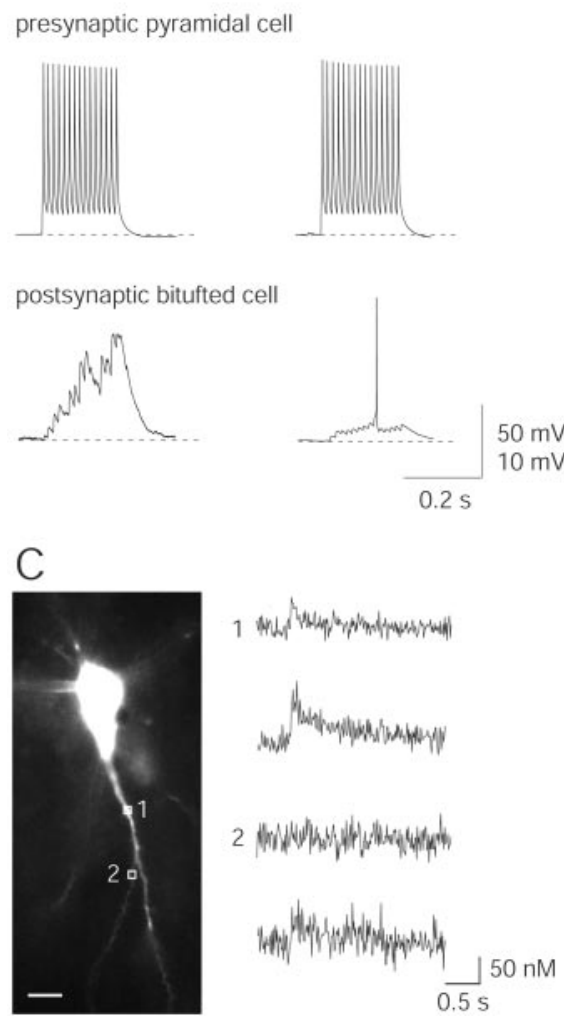

Figure 3. Dendritic $\mathrm{Ca}^{2+}$ influx evoked by subthreshold and suprathreshold EPSPs during unitary synaptic stimulation. $A, A$ train of $15 \mathrm{APs}$ (at $50 \mathrm{~Hz}$ ) was evoked in a pyramidal neuron by current injection via a somatic pipette (upper traces). This train elicited subthreshold and suprathreshold EPSPs in a postsynaptic bitufted interneuron (lower traces). Note the larger scale bar for subthreshold EPSPs. Resting potentials were $-75 \mathrm{mV}$ for the pyramidal cell and $-59 \mathrm{mV}$ for the interneuron. $B$, Fluorescence image of a bitufted neuron filled via the somatic pipette with $250 \mu \mathrm{m}$ fura-2. Selected regions for $\mathrm{Ca}^{2+}$ fluorescence imaging, located on dendrites are marked by rectangles and numbered 1-13. Corresponding $\left[\mathrm{Ca}^{2+}\right]_{\mathrm{i}}$ transients evoked by suprathreshold EPSPs-APs in the bitufted neuron are shown on the right. The presynaptic pyramidal neuron, which was not loaded with dye, was stimulated to generate a train of $10 \mathrm{APs}$ at $50 \mathrm{~Hz}$. At all locations the sequence EPSPs-APs evoked a transient rise in dendritic $\left[\mathrm{Ca}^{2+}\right]_{\mathrm{i}}$. Note the differences in the amplitude of $\mathrm{Ca}^{2+}$ signals. Fluorescence traces are averages of five sweeps. Scale bar, $10 \mu \mathrm{m}$. C, Two classes of dendritic $\left[\mathrm{Ca}^{2+}\right]_{i}$ transients. Fluorescence image of a bitufted neuron with two dendritic sites selected for $\mathrm{Ca}^{2+}$ imaging (left) and corresponding $\left[\mathrm{Ca}^{2+}\right]_{i}$ transients during subthreshold and suprathreshold EPSPs (right). Region 1 showed $\mathrm{Ca}^{2+}$ influx during subthreshold and suprathreshold EPSPs (upper traces), whereas region 2 showed $\mathrm{Ca}^{2+}$ influx only during suprathreshold EPSPs. Stimulation of the presynaptic pyramidal neuron, which is not visible, was evoked with $10 \mathrm{APs}$ ( $50 \mathrm{~Hz}$ ). Traces are single sweeps without smoothing. Scale bar, $10 \mu \mathrm{m}$.

al., 2001), but branch point failures in L2/3 pyramid axons are unlikely to contribute to the variability (Köster and Sakmann, 2000). Furthermore, L2/3 pyramidal cell collaterals form several synaptic contacts with bitufted interneurons at different dendritic locations. Together, this implies that an individual contact could be postsynaptically silent even during a train of APs in the presynaptic pyramidal neuron, which evokes EPSPs. Indeed, in $15 \pm 4 \%$ of the trials ( $n=5$ pairs) during subthreshold EPSPs a $\left[\mathrm{Ca}^{2+}\right]_{\mathrm{i}}$ transient was not recorded, suggesting that the peak amplitude of postsynaptic $\left[\mathrm{Ca}^{2+}\right]_{\mathrm{i}}$ transients may strongly vary at a single contact, mostly because the presynaptic $\mathrm{Ca}^{2+}$ influx is not always evoking release. The dendritic $\mathrm{Ca}^{2+}$ signals evoked during subthreshold EPSPs did not correlate with the amplitude of the somatically recorded depolarization as measured in $112\left[\mathrm{Ca}^{2+}\right]_{\mathrm{i}}$ transients evoked during subthreshold EPSPs (11 cell pairs; linear regression with $r=0.11$; data not shown). The coefficient of variation $(\mathrm{CV})$ of normalized peak $\left[\mathrm{Ca}^{2+}\right]_{\mathrm{i}}$ transients during subthreshold EPSPs was $0.29(n=109$ sweeps from 12 synaptic contacts). For comparison, the $\mathrm{CV}$ was significantly smaller for peak $\left[\mathrm{Ca}^{2+}\right]_{\mathrm{i}}$ evoked by either suprathreshold EPSPs $(C V=0.20 ; n=95$ sweeps recorded from 12 synaptic contacts; $t$ test; $p<0.003$ ) or by single backpropagating APs evoked by somatic current injection $(\mathrm{CV}=0.17 ; n=43$ sweeps from 13 synaptic contacts; $t$ test; $p<0.002)$. The latter two CVs were not significantly different $(t$ test; $p>0.2)$.

\section{Dual dye loading with Alexa 594}

En passant boutons of L2/3 pyramidal neurons show a substantial $\mathrm{Ca}^{2+}$ influx during repetitive excitation by 10 APs up to $100 \mathrm{~Hz}$ (Köster and Sakmann, 2000). To confirm the predominantly postsynaptic origin of the $\left[\mathrm{Ca}^{2+}\right]_{\mathrm{i}}$ transients at dendritic hot spots we loaded the presynaptic cell with the $\mathrm{Ca}^{2+}$ insensitive dye Alexa $594(10 \mu \mathrm{M} ; n=4)$. In three experiments the interneurons were loaded with OGB-1 $(200 \mu \mathrm{M})$. Dendritic $\left[\mathrm{Ca}^{2+}\right]_{\mathrm{i}}$ transients were evoked during synaptic stimulation in all experiments (data not shown) at the individual contacts.

\section{Simultaneous measurement of presynaptic and postsynaptic $\mathrm{Ca}^{2+}$ influx at a synaptic contact}

To unequivocally identify postsynaptic $\left[\mathrm{Ca}^{2+}\right]_{\mathrm{i}}$ transients and their spread along the dendrite we measured presynaptic $\mathrm{Ca}^{2+}$ influx into boutons and simultaneously postsynaptic $\mathrm{Ca}^{2+}$ transients during unitary synaptic stimulation using two-photon excitation (Denk et al., 1990). Pyramidal-to-bitufted cell pairs were selectively loaded with two different $\mathrm{Ca}^{2+}$ sensitive dyes, rhod-2 $(275 \mu \mathrm{M})$ and OGB$1(200 \mu \mathrm{M})$, respectively (Fig. 5A). Synaptic contacts were identified by searching for axon and dendritic segments that were in close proximity. Figure 5 illustrates a contact at which in the pyramidal neuron three APs $(10 \mathrm{~Hz})$ were evoked. Each AP elicited a presynaptic $\left[\mathrm{Ca}^{2+}\right]_{i}$ transient. These evoked only two EPSPs in the bitufted cell, because the first AP failed to evoke an EPSP (Fig. 5C). Only during the EPSP evoked by the second AP was a dendritic $\mathrm{Ca}^{2+}$ signal recorded (Fig. 5B,C). These differences between the occurrence of EPSPs and of postsynaptic $\left[\mathrm{Ca}^{2+}\right]_{\mathrm{i}}$ transients suggest that the bouton responded to the second $\mathrm{AP}$ with release of glutamate, but failed release in response to the first and third AP. Thus, the EPSPs during which a postsynaptic $\left[\mathrm{Ca}^{2+}\right]_{\mathrm{i}}$ transient was not recorded were presumably evoked at other synaptic contacts. Similar results were obtained for two other synaptic contacts located on dendritic shafts in two additional cell pairs.

The peak amplitude of postsynaptic $\mathrm{Ca}^{2+}$ transients $\Delta F / F$ varied between 0.30 and 2.25 (Fig. $6 \mathrm{~A}$ ) and increased with the size of the EPSP (Fig. $6 B)(n=3$ synaptic contacts from three pairs; linear regression $r=0.54$ ). This suggests a depolarizationdependent mechanism for $\mathrm{Ca}^{2+}$ influx at the postsynaptic site, most likely via NMDA receptor (NMDAR) channels relieved from $\mathrm{Mg}^{2+}$ block. The fluorescence transients, which were 

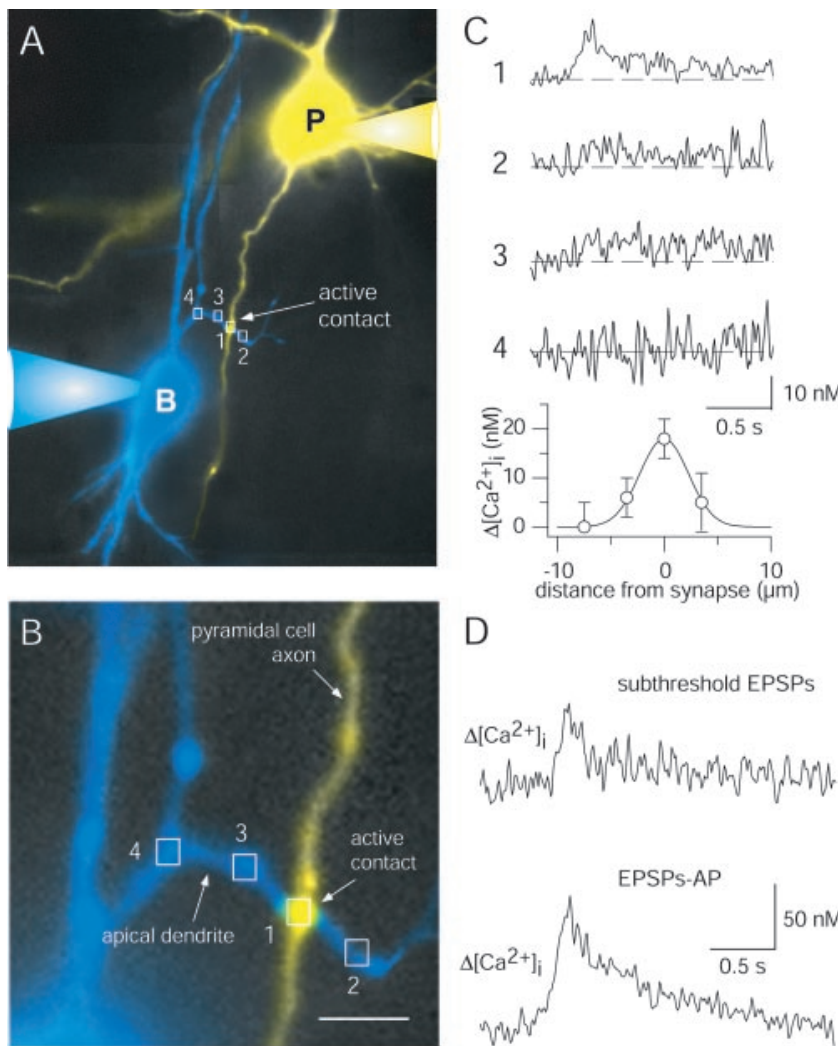

D
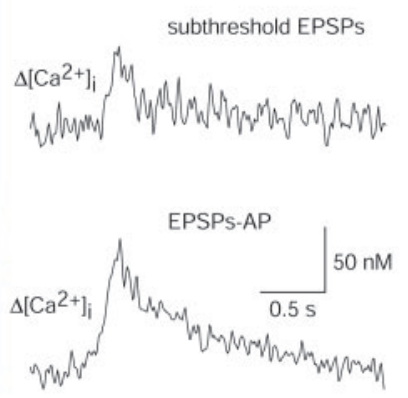

Figure 4. Identification of single synaptic contacts between pyramidal and bitufted cell by fluorescence and $\mathrm{Ca}^{2+}$ imaging. $A$, Pseudocolor fluorescence image of synaptically connected pyramidal (yellow) and bitufted (blue) neuron. The presynaptic pyramidal cell was loaded with $400 \mu \mathrm{m}$ mag-fura-2 for visualization. The postsynaptic bitufted neuron was filled with $250 \mu \mathrm{m}$ fura-2 for $\mathrm{Ca}^{2+}$ imaging. Rectangles mark selected dendritic regions for $\mathrm{Ca}^{2+}$ imaging. $B$, Higher magnification of the intersection between an axon collateral of the pyramidal neuron and a dendritic branch of the bitufted interneuron shown in A. Scale bar, $5 \mu \mathrm{m}$. C, Amplitude of $\left[\mathrm{Ca}^{2+}\right]_{\mathrm{i}}$ transients evoked by subthreshold EPSPs in the bitufted neuron dendrite at a single active synaptic contact and adjacent dendritic regions (top graphs). Numbers refer to regions shown in $A$ and $B$. Stimulation of the presynaptic pyramidal neuron evoked a train of $10 \mathrm{APs}$ (50 $\mathrm{Hz}$ ). The bottom graph shows the distribution of $\left[\mathrm{Ca}^{2+}\right]_{\mathrm{i}}$ transient peak amplitudes at and around the synaptic contact. The data points were fitted by a Gaussian with a half-width of 5 $\mu \mathrm{m}$. D, Difference in $\left[\mathrm{Ca}^{2+}\right]_{\mathrm{i}}$ transients at an active synaptic contact after subthreshold and suprathreshold EPSPs. In the presynaptic pyramidal neuron, $15 \mathrm{APs}$ at $50 \mathrm{~Hz}$ were initiated. Data are taken from the cell pair shown in Figure $9 A$. For postsynaptic membrane potentials see Figure $9 B$ (bottom traces).

evoked by a single backpropagating AP, evoked $\mathrm{Ca}^{2+}$ influx, mostly through voltage-dependent calcium channels (VDCCs) (Kaiser et al., 2001), which was in the range of the smallest EPSPevoked $\mathrm{Ca}^{2+}$ transients and, on average, $60 \%$ of the EPSP evoked $\mathrm{Ca}^{2+}$ transients.

The diffusion of $\mathrm{Ca}^{2+}$ away from the point of entry along the dendrite was examined in one experiment, also with two-photon excitation. The postsynaptic peak fluorescence change $3 \mu \mathrm{m}$ away from the synaptic site was $16 \%$ of the peak at the synaptic contact, whereas presynaptic $\mathrm{Ca}^{2+}$ transients were restricted to the site of contact (Fig. $7 A, B$ ).

The fluorescence changes recorded with two-photon excitation measurements thus confirm the predominantly postsynaptic origin of $\left[\mathrm{Ca}^{2+}\right]_{\mathrm{i}}$ transients at single synaptic contacts and directly demonstrate the dissociation between the occurrence of EPSPs in a connection comprising several contacts and the local dendritic $\left[\mathrm{Ca}^{2+}\right]_{\mathrm{i}}$ transients.

\section{Ion channels mediating dendritic $\mathrm{Ca}^{2+}$ influx}

To address the question, which ion channels contribute to the dendritic $\mathrm{Ca}^{2+}$ influx evoked by subthreshold EPSPs, we bathapplied the NMDAR channel antagonist APV $(100 \mu \mathrm{M})$ before stimulation (Fig. $8 A, B$ ). In three of five experiments, $\left[\mathrm{Ca}^{2+}\right]_{\mathrm{i}}$ transients detected at resting potential $(-61.5 \pm 3.8 \mathrm{mV})$ were completely blocked. In two other experiments $\left[\mathrm{Ca}^{2+}\right]_{\mathrm{i}}$ transients were reduced to $32 \%$ of control. In two experiments, the $\mathrm{Ca}^{2+}$ signal reappeared after the washout of APV. APV itself did not change the peak amplitude of unitary EPSPs $(0.35 \pm 0.12 \mathrm{mV}$ in control and $0.37 \pm 0.14 \mathrm{mV}$ in the presence of APV; $n=4 ; t$ test; $p>0.6)$. In addition, the probability of evoking suprathreshold EPSPs by repetitive presynaptic APs decreased only by $8 \pm 2 \%$ ( $n=4$ cell pairs) in APV. The remaining $\mathrm{Ca}^{2+}$ signal could reflect $\mathrm{Ca}^{2+}$ influx through VDCCs (Jaffe et al., 1994; Schiller et al., 1998) activated by depolarization mediated by AMPA receptor (AMPAR) channels, influx through calcium-permeable AMPAR (CP-AMPAR) channels (Goldberg et al., 2003), and also a presynaptic contribution to the $\mathrm{Ca}^{2+}$ signal caused by overlap of the fura-2 and mag-fura-2 excitation spectra (see Materials and Methods). However, the contribution of CP-AMPARs is unlikely, because single EPSPs were insensitive to $50 \mu \mathrm{M}$ extracellular spermine, a blocker of CP-AMPAR channels (Kamboj et al., 1995; Rozov and Burnashev, 1999). In five experiments, amplitudes of single EPSPs in the presence of spermine were $1.05 \pm$ 0.37 of control condition (data not shown). In one additional experiment, both EPSPs and synaptic $\mathrm{Ca}^{2+}$ transients were insensitive to spermine $(29 \pm 4 \mathrm{nM}$ control; $38 \pm 8 \mathrm{nM} 50 \mu \mathrm{M}$ spermine; data not shown).

To further quantify the contribution of NMDAR channels to synaptically evoked $\mathrm{Ca}^{2+}$ signals, the membrane potential of bitufted interneurons was hyperpolarized to $-90 \mathrm{mV}$ by somatic current injection. The peak $\left[\mathrm{Ca}^{2+}\right]_{\mathrm{i}}$ amplitudes evoked by subthreshold EPSPs were reduced in 7 of 11 synaptic contacts by $18 \pm 4 \%$ compared with those recorded at the resting potential. At the other four contacts the peak $\left[\mathrm{Ca}^{2+}\right]_{\mathrm{i}}$ transients were increased by $61 \pm 29 \%$. On average, the peak amplitudes of $\left[\mathrm{Ca}^{2+}\right]_{i}$ transients did not change compared with controls (data not shown), presumably because of variable depolarizations at the identified contacts during synaptic stimulation.

In 11 additional experiments, synaptic $\left[\mathrm{Ca}^{2+}\right]_{\mathrm{i}}$ transients were recorded under voltage clamp at $-90,-60$, and $-50 \mathrm{mV}$ (Fig. 8C). Compared with the normalized peak $\left[\mathrm{Ca}^{2+}\right]_{\mathrm{i}}$ amplitude recorded at $-60 \mathrm{mV}$, the peak $\left[\mathrm{Ca}^{2+}\right]_{\mathrm{i}}$ amplitudes were reduced at $-90 \mathrm{mV}$ to $0.89 \pm 0.19(n=10$ cell pairs $)$, and significantly increased to $1.22 \pm 0.16(n=5$ cell pairs $)$ at $-50 \mathrm{mV}$ (two-tailed paired $t$ test; ${ }^{\star} p<0.05$ ) (Fig. 8D). Presumably, in both current- and voltage-clamp experiments, $\mathrm{Ca}^{2+}$ entered through NMDAR channels because of an incomplete $\mathrm{Mg}^{2+}$ block, even at hyperpolarized membrane potentials (Wollmuth et al., 1998; Kovalchuk et al., 2000). The fact that most synaptic contacts were located close to the soma ( $33 \pm 18 \mu \mathrm{m} ; n=27$ ) renders incomplete control of dendritic membrane potential a less likely possibility.

To further test the hypothesis that synaptic $\mathrm{Ca}^{2+}$ was mediated mainly by NMDAR channels, we used $10 \mu \mathrm{M}$ NBQX to block AMPAR channels. NBQX completely blocked the EPSPs $(3 \pm 2 \%$ of control; $n=7$ cell pairs) and recovered to 0.24 of control after washout $(n=2)$. Synaptic $\left[\mathrm{Ca}^{2+}\right]_{\mathrm{i}}$ transients could not be recorded during subthreshold synaptic stimulation (also indicating a minimal presynaptic contribution). Therefore, we evoked a single backpropagating AP in the interneuron by somatic current injection coincident with synaptic stimulation. The backpropa- 
A
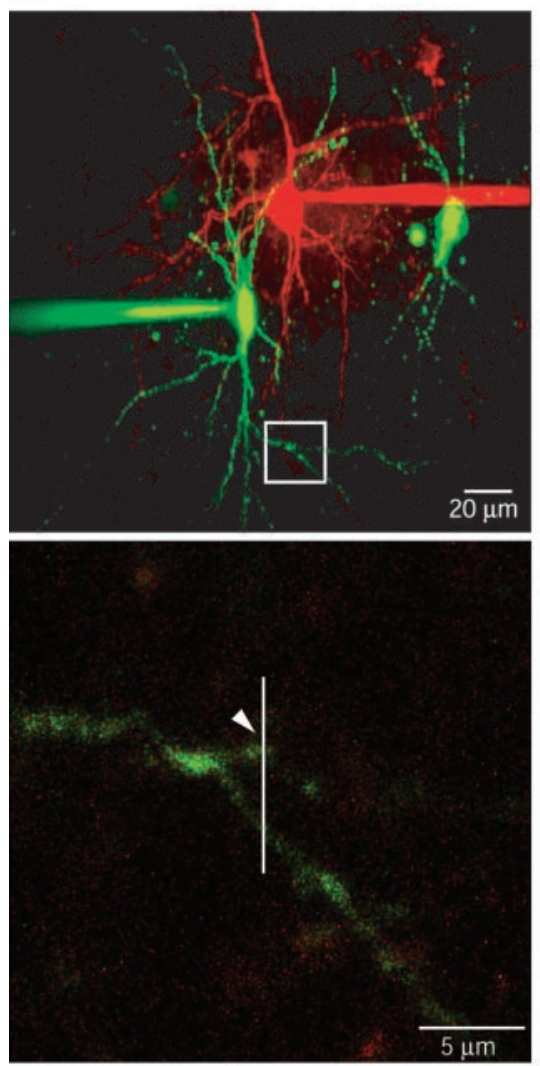

B
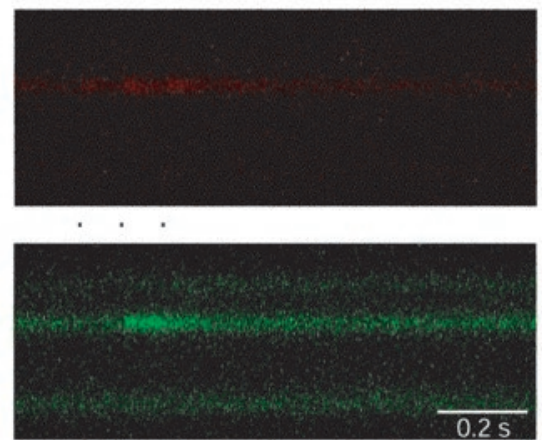

C

$\mathrm{V}_{\mathrm{m}}$

$\Delta \mathrm{F} / \mathrm{F}$
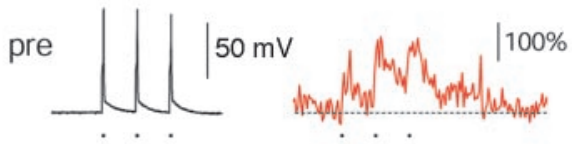

post
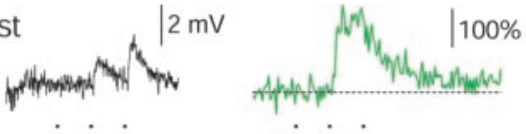

$\overline{0.2 \mathrm{~s}}$

Figure 5. Presynaptic and postsynaptic $\mathrm{Ca}^{2+}$ influx at single synaptic contacts recorded by using two-photon excitation fluorescence microscopy. A, top, Fluorescence image of a pyramid-to-bitufted cell pair filled with rhod-2 and 0GB-1, respectively. The pyramidal neuron is shown in red, the interneuron in green. The region with an identified synaptic contact is marked by the rectangle and shown at higher magnification at the bottom. The arrowhead points to a synaptic contact. The presynaptic axon is hardly visible, but lightens up during $\mathrm{Ca}^{2+}$ influx (see $B$ ). Line scans shown in $B$ were performed at the region indicated by the white vertical line. $B$, Fluorescence line scans recorded during unitary synaptic stimulation on the presynaptic bouton (red) and the postsynaptic dendrite (green). In the pyramidal neuron three APs were evoked at $10 \mathrm{~Hz}$ (see C). C, Each of the three APs evoked in the pyramidal neuron gave rise to a $\mathrm{Ca}^{2+}$ influx into the presynaptic terminal (top traces, same experiment shown in $B$ ). The postsynaptic neuron responded with two EPSPs, but only during one was a postsynaptic $\mathrm{Ca}^{2+}$ signal also measured (lower traces). Presumably, the second EPSP was evoked at another contact. Fluorescence data were not filtered. Note: $\mathrm{No} \mathrm{Ca}^{2+}$ transient was recorded on the other dendrite also covered by the line scan (see $B$ ), indicating the synaptic origin of the $\mathrm{Ca}^{2+}$ signals.

gating AP was sufficient to relieve NMDAR channels from the $\mathrm{Mg}^{2+}$ block, which resulted in additional $\mathrm{Ca}^{2+}$ influx (Fig. $8 \mathrm{E}$ ). The normalized peak $\left[\mathrm{Ca}^{2+}\right]_{\mathrm{i}}$ amplitude increased to $1.18 \pm 0.14$ ( $n=3$ cell pairs) of the control value (Fig. $8 F$ ).

The possible contribution of VDCCs to $\left[\mathrm{Ca}^{2+}\right]_{\mathrm{i}}$ transients evoked in bitufted interneurons by subthreshold EPSPs was comparatively small because in three pairs APV completely blocked postsynaptic calcium signals at -60 and $-90 \mathrm{mV}$. Furthermore, in two experiments with APV, no $\left[\mathrm{Ca}^{2+}\right]_{\mathrm{i}}$ transients could be recorded in close proximity to the synaptic contact, indicating that AMPAR-channel-induced depolarization did not activate VDCCs during subthreshold EPSPs.

We further addressed the possibility that low-voltageactivated (LVA) calcium channels could contribute to postsynaptic $\left[\mathrm{Ca}^{2+}\right]_{\mathrm{i}}$ transients. Transients evoked by single EPSPs (Fig. $6 B$, filled circles) were in the range of larger transients evoked by a single backpropagating AP (Fig. $6 \mathrm{~B}$, rectangle). The mean EPSP amplitude recorded at the soma was $1.71 \pm 0.7 \mathrm{mV}$ (45 single EPSPs from three cell pairs). The somatically measured EPSP amplitudes probably underestimate the actual dendritic depolarization at the contact. However, they presumably represent the sum of inputs at different synaptic contacts. Together, these data indicate only a very small contribution of LVA calcium channels to the dendritic calcium signal, if any.

A possible contribution of $\mathrm{Ca}^{2+}$ released from internal stores could not be ruled out, because $25 \mu \mathrm{M}$ cyclopiazonic acid reduced EPSPs concomitant with a reduction of postsynaptic $\mathrm{Ca}^{2+}$ transients ( $n=3$ cell pairs).

In summary, the results suggest that the $\left[\mathrm{Ca}^{2+}\right]_{\mathrm{i}}$ transients measured at single synaptic contacts when evoked by subthreshold EPSPs were predominantly of postsynaptic origin and were mediated by NMDAR channels. The dominant contribution of NMDARs to dendritic calcium signaling induced by subthreshold synaptic stimulation was also shown recently in three classes of interneurons in the visual cortex, including one class that expressed high $\mathrm{Ca}^{2+}$-permeable AMPAR channels (Goldberg et al., 2003).

\section{Spatial profile of $\left[\mathrm{Ca}^{2+}\right]_{\mathrm{i}}$ transients}

Measurements of $\left[\mathrm{Ca}^{2+}\right]_{\mathrm{i}}$ transients at single contacts and adjacent dendritic regions (Fig. 9A,B) of six cell pairs revealed that $\mathrm{Ca}^{2+}$ accumulation at the site of $\mathrm{Ca}^{2+}$ influx during subthreshold stimulation was detectable within approximately \pm 10 $\mu \mathrm{m}$ along the dendritic branch. The distribution of dendritic $\left[\mathrm{Ca}^{2+}\right]_{\mathrm{i}}$ transients in the proximity of single contacts is shown in Figure $9 C$ (top). The solid line represents a fitted Gaussian function with a half-width of $5 \mu \mathrm{m}$. This small width suggests that the attenuation in the rise of $\left[\mathrm{Ca}^{2+}\right]_{\mathrm{i}}$ on both sides of the contact is mostly attributable to rapid diffusion of $\mathrm{Ca}^{2+}$ from the synaptic contact and that the influx is limited by $\mathrm{Ca}^{2+}$ buffering by the endogenous buffers and probably distorted by the added exogenous $\mathrm{Ca}^{2+}$ indicator (Naraghi and Neher, 1997).

\section{Enhancement of synaptic $\mathrm{Ca}^{2+}$ influx by backpropagating APs}

When summated EPSPs were suprathreshold, $\left[\mathrm{Ca}^{2+}\right]_{\mathrm{i}}$ transients at synaptic contacts increased in amplitude by approximately twofold. This increase was most likely caused by the backpropagating dendritic AP evoking a dendritic $\mathrm{Ca}^{2+}$ influx that added to the $\mathrm{Ca}^{2+}$ influx evoked by EPSPs. Figure $9 B$ compares $\left[\mathrm{Ca}^{2+}\right]_{i}$ transients recorded from a single contact and adjacent dendritic segments after subthreshold and suprathreshold EPSPs. Normalized $\left[\mathrm{Ca}^{2+}\right]_{\mathrm{i}}$ amplitudes measured at six contacts (Fig. 9C, top and middle graphs) show that the peak amplitudes of $\left[\mathrm{Ca}^{2+}\right]_{i}$ transients evoked by suprathreshold EPSPs (EPSP-AP sequence) were higher than those evoked either by subthreshold EPSPs (Fig. 9C, top) or by a backpropagating AP alone (Fig. 9C, bottom). These results strongly suggest that $\left[\mathrm{Ca}^{2+}\right]_{\mathrm{i}}$ transients, when evoked by suprathreshold EPSPs, reflect the $\mathrm{Ca}^{2+}$ influx via syn- 
A

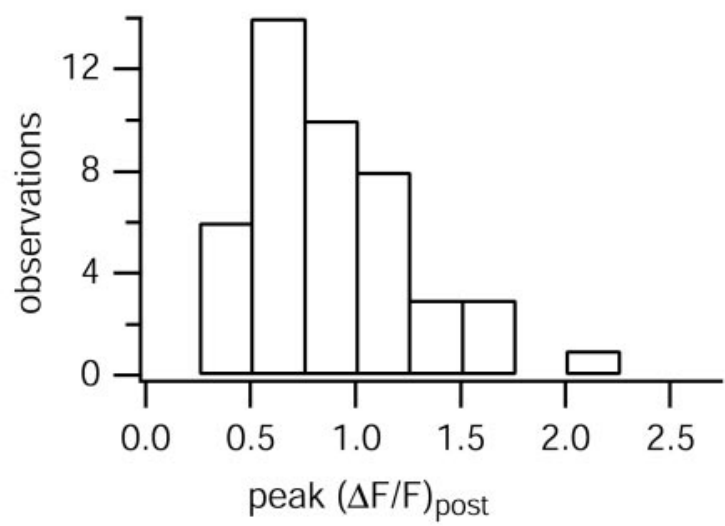

B

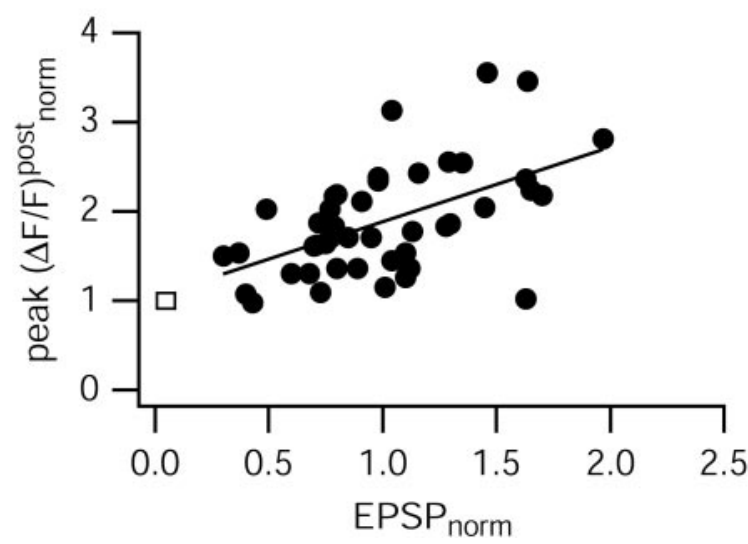

Figure 6. Postsynaptic $\mathrm{Ca}^{2+}$ transients at single contacts. $A$, Histogram of postsynaptic peak $\Delta F / F$ evoked by single EPSPs. The mean peak $\Delta F / F$ was $0.89 \pm 0.40(n=45$ single sweeps). Data are pooled from three synaptic contacts of three pairs. $B$, Postsynaptic peak $\Delta F / F$ increases with EPSP size (filled circles) (regression $r=0.54$ ). Data are pooled from $n=45$ EPSP-evoked postsynaptic $\mathrm{Ca}^{2+}$ transients from three synaptic contacts of three cell pairs. Peak fluorescence amplitudes and EPSPs were normalized to mean values for each cell pair. For comparison also, the peak $\Delta F / F$ evoked by a single backpropagating AP at the synaptic contact is shown (rectangle, placed arbitrarily).

aptic NMDAR channels and dendritic VDCCs, which transiently open during the backpropagating AP.

\section{Summation of $\mathrm{Ca}^{2+}$ influx at synaptic contacts}

To delineate the relative contribution of EPSPs and backpropagating APs in evoking dendritic $\mathrm{Ca}^{2+}$ influx at synaptic contacts, the $\left[\mathrm{Ca}^{2+}\right]_{\mathrm{i}}$ transients evoked by subthreshold EPSPs were compared at the same contact to those evoked by a backpropagating AP (Fig. $10 A-C$ ). At most contacts, the peak $\left[\mathrm{Ca}^{2+}\right]_{\mathrm{i}}$ transients evoked by a train of 10-15 summated EPSPs and those evoked by a single backpropagating AP were comparable in size (Fig. 10D). When EPSPs were suprathreshold and evoked an AP, which occurred $177 \pm 60 \mathrm{msec}$ after the onset of presynaptic stimulation $\left(n=91\right.$ trials from 12 cell pairs), the peak $\left[\mathrm{Ca}^{2+}\right]_{\mathrm{i}}$ increased approximately twofold (Fig. $10 \mathrm{E}$ ). The peak $\left[\mathrm{Ca}^{2+}\right]_{\mathrm{i}}$ was significantly ( $t$ test; $p<0.002$ ) larger than the peak calculated as the arithmetic sum of the $\left[\mathrm{Ca}^{2+}\right]_{\mathrm{i}}$ transients evoked by subthreshold EPSPs and by a single backpropagating AP initiated by somatic current injection (Fig. $10 \mathrm{~F}$ ). The higher $\mathrm{Ca}^{2+}$ signals generated by suprathreshold EPSPs could be caused by several factors, such as unblocking of synaptic NMDAR channels from $\mathrm{Mg}^{2+}$ during

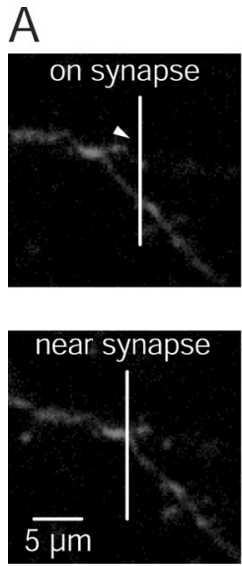

B

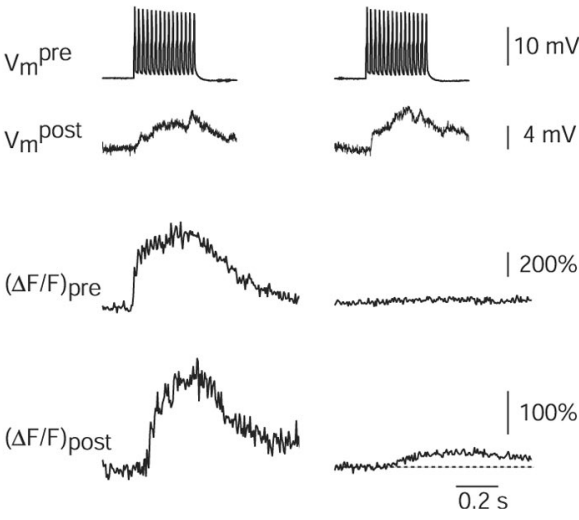

Figure 7. Postsynaptic $\mathrm{Ca}^{2+}$ diffusion. $A$, Fluorescence image of a dendrite of a bitufted neuron receiving input from a pyramidal neuron (same cell pair shown in Fig. 5). The arrowhead points to an identified synaptic contact. The vertical lines indicate the regions for line scans on the synaptic contact (top) and $2.7 \mu$ m apart (bottom). $B$, Diffusion of $\mathrm{Ca}^{2+}$ away from the point of entry along the dendrite. Presynaptic and postsynaptic $\Delta F / F$ transients recorded at the contact (left) and $2.7 \mu \mathrm{m}$ away (right). Fifteen APs at $50 \mathrm{~Hz}$ were evoked in the pyramidal neuron. Fluorescence traces are averages of three to five sweeps.

the dendritic AP or boosting of the dendritic APs. Synaptically evoked APs also show a longer duration, attributable to inactivation of $\mathrm{K}^{+}$channels (A. Korngreen, K. M. M. Kaiser, and Y. Zilberter, unpublished observations).

\section{Discussion}

The results demonstrate that hot spots of enhanced postsynaptic $\mathrm{Ca}^{2+}$ influx exist in the dendrites of bitufted interneurons at the sites of individual, active synaptic contacts. They are established by en passant boutons of L2/3 pyramid axon collaterals on the dendritic shafts of the bitufted interneurons. The hot spots comprise a dendritic segment with an apparent half-width of $\sim 10$ $\mu \mathrm{m}$, probably reflecting buffered diffusion of the $\mathrm{Ca}^{2+}$ entering the dendrite at a postsynaptic density. Dendritic $\mathrm{Ca}^{2+}$ influx at single contacts is mediated predominantly by NMDAR channels in combination with $\mathrm{Ca}^{2+}$ influx through VDCCs. Under our experimental conditions of indicator loading, the peak transient can reach values up to $200 \mathrm{nM}$ of $\left[\mathrm{Ca}^{2+}\right]_{\mathrm{i}}$, and the transient lasts for $\sim 200 \mathrm{msec}$.

\section{Size of a dendritic $\left[\mathrm{Ca}^{2+}\right]_{\mathrm{i}}$ transient at active synaptic contacts}

Because the fluorescence indicator fura-2 $(250 \mu \mathrm{M})$ acts as an exogenous $\mathrm{Ca}^{2+}$ buffer, the amplitude of volume-averaged $\left[\mathrm{Ca}^{2+}\right]_{\mathrm{i}}$ transients is reduced and their decay time is longer in comparison with that expected for a "native" dendrite. In addition, when the $\mathrm{Ca}^{2+}$ influx is locally restricted, a mobile buffer like fura- 2 tends to decrease $\left[\mathrm{Ca}^{2+}\right]_{\mathrm{i}}$ amplitudes because of facilitated diffusion, and it also interferes with the lateral spread of the $\mathrm{Ca}^{2+}$ signals. Whether the measured lateral spread is an overestimation or underestimation depends on several factors, such as the diffusion constant of fura- 2 and the on-rate of $\mathrm{Ca}^{2+}$ binding to fura-2 compared with those of the endogenous mobile buffers in the dendrite. For cultured hippocampal neurons, it was suggested that an exogenous buffer overestimates the measured $\mathrm{Ca}^{2+}$ diffusion and that the dominant endogenous buffer is relatively immobile, restricting the lateral spread of $\mathrm{Ca}^{2+}$ to $<3 \mu \mathrm{m}$ (Murthy et al., 2000).

Bitufted interneurons have a $\mathrm{Ca}^{2+}$ binding ratio of $\sim 285$ (Kaiser et al., 2001) and the incremental $\mathrm{Ca}^{2+}$ binding ratio of 
A

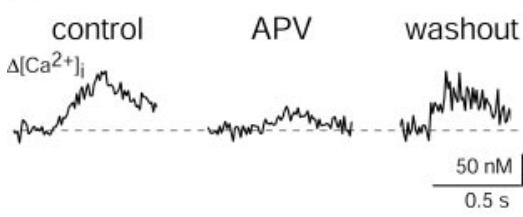

C

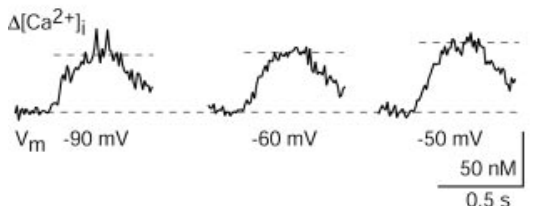

E

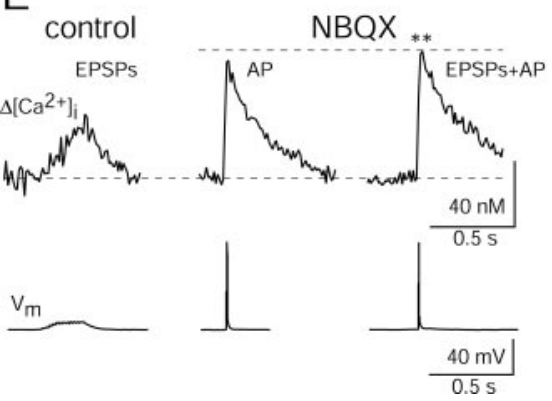

B
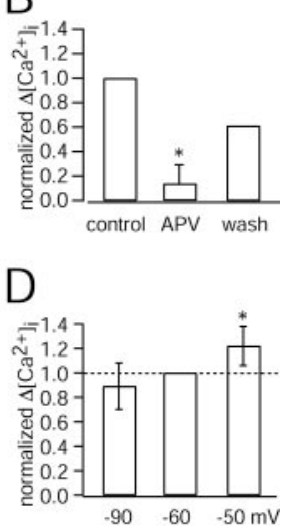

$\mathrm{F}$

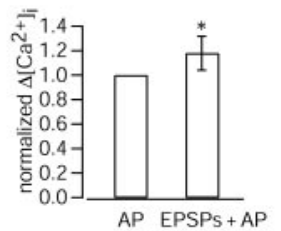

Figure 8. Ion channels mediating dendritic $\mathrm{Ca}^{2+}$ influx. $A, \mathrm{Ca}^{2+}$ influx at a synaptic contact evoked by a train of 15 presynaptic APs in control conditions (left), during application of $100 \mu \mathrm{M}$ APV (middle), and after washout (right). Traces are averages of six, six, and nine sweeps, respectively. The interneuron was voltage-clamped at $-60 \mathrm{mV}$. B, Pooled data of normalized peak $\left[\mathrm{Ca}^{2+}\right]_{\mathrm{i}}$ amplitudes in control and after bath application of APV were significantly different (two-tailed paired $t$ test; ${ }^{*} p<0.026$ ). Data are taken from $n=5$ cell pairs (washout from two cell pairs). $C, \mathrm{Ca}^{2+}$ influx at a synaptic contact evoked by a train of 15 presynaptic $A P$ s when the soma of the bitufted neuron was voltage-clamped at -90 (left), -60 (middle), and -50 $\mathrm{mV}$ (right). Traces are averages of two, three, and three sweeps, respectively. D, Pooled data of normalized peak $\left[\mathrm{Ca}^{2+}\right]_{;}$amplitudes at different holding potentials. Data are from 11 pairs. The increase of $\left[\mathrm{Ca}^{2+}\right]_{i}$ amplitudes at $-50 \mathrm{mV}$ compared with -60 and $-90 \mathrm{mV}$ was significant (two-tailed paired $t$ test; ${ }^{*} p<0.05$ and ${ }^{*} p<0.01$, respectively). $E, \mathrm{Ca}^{2+}$ influx at a synaptic contact evoked by a train of 15 presynaptic APs in control condition (left). After the application of $10 \mu \mathrm{MNQQX}$, the $\left[\mathrm{Ca}^{2+}\right]_{\mathrm{i}}$ amplitude evoked by a single, somatically evoked backpropagating AP (middle) was increased significantly when combined with synaptic stimulation (right) ( $t$ test; ${ }^{* *} p<0.001$ ). Traces are averages of 4,24 , and 25 sweeps, respectively. F, Pooled data for normalized peak $\left[\mathrm{Ca}^{2+}\right]_{i}$ amplitudes. Data are from three pairs. The increase of $\left[\mathrm{Ca}^{2+}\right]_{i}$ amplitude was significant $\left(t\right.$ test; $\left.{ }^{*} p<0.025\right)$.

$250 \mu \mathrm{M}$ fura-2 for bitufted neurons is $\sim 600$. Thus, the $\mathrm{Ca}^{2+}$ binding ratio of bitufted neuron dendrites is approximately threefold larger when loaded with $250 \mu \mathrm{M}$ fura-2 [Kaiser et al. (2001), their Fig. 1]. Measured dendritic $\left[\mathrm{Ca}^{2+}\right]_{\mathrm{i}}$ transients evoked by subthreshold EPSPs were typically in the range of $30-$ $100 \mathrm{~nm}$. Thus, these values underestimate the amplitudes of $\left[\mathrm{Ca}^{2+}\right]_{\mathrm{i}}$ transients in native dendrites by a factor of $\sim 3$, suggesting that without buffer loading the dendritic $\left[\mathrm{Ca}^{2+}\right]_{\mathrm{i}}$ transients during subthreshold EPSPs can reach values of $80-250 \mathrm{nM}$. When EPSPs become suprathreshold and evoke an AP, we estimate that the peak amplitude of dendritic $\left[\mathrm{Ca}^{2+}\right]_{\mathrm{i}}$ transients, without buffer loading, increases to $130-450 \mathrm{~nm}$ at single contacts.

The decay time constants of dendritic $\left[\mathrm{Ca}^{2+}\right]_{\mathrm{i}}$ transients, when evoked either by subthreshold EPSPs or a single backpropagating AP, were similar. This observation suggests that the decay time of dendritic $\left[\mathrm{Ca}^{2+}\right]_{i}$ transients at synaptic contacts in native dendrites is $\sim 200 \mathrm{msec}$, as extrapolated from experiments

A

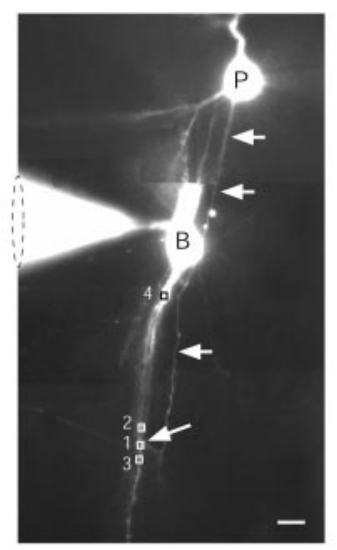

B
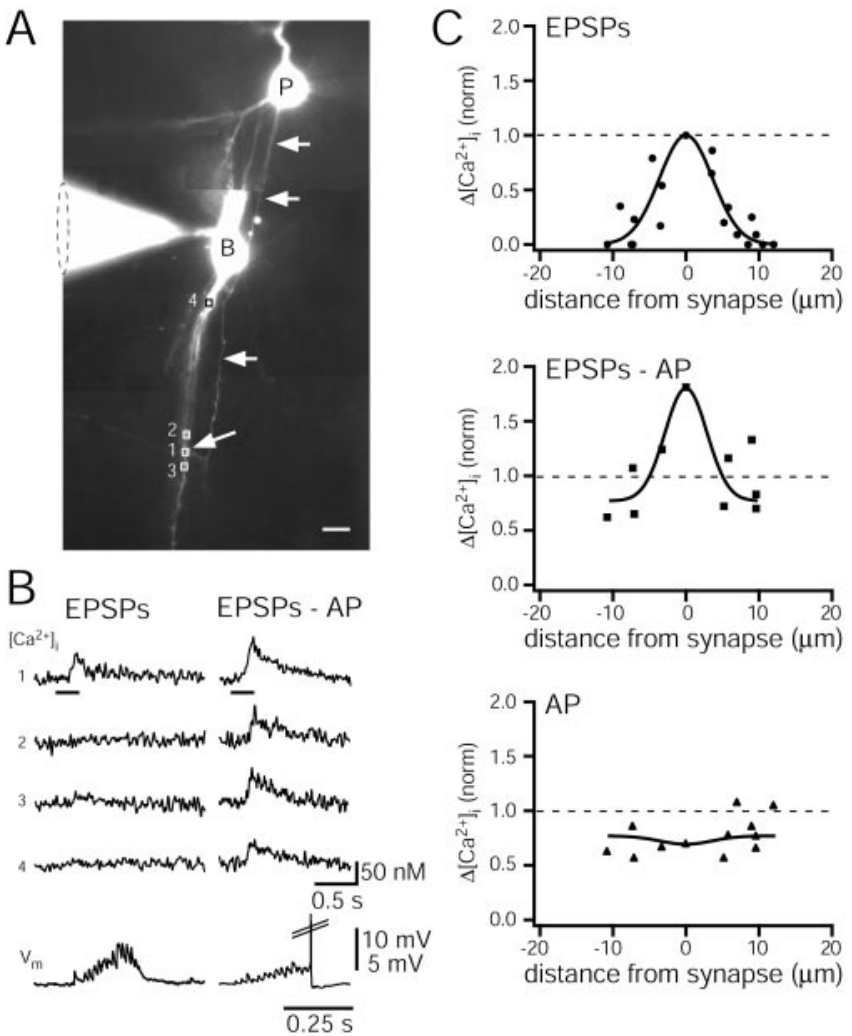

Figure 9. Spatial profile of dendritic $\left[\mathrm{Ca}^{2+}\right]$ transients at single synaptic contacts. A, Fluorescence image of a synaptically connected pyramidal and bitufted neuron cell pair. The bitufted neuron was loaded with $250 \mu \mathrm{m}$ fura-2, and the pyramidal cell with $400 \mu \mathrm{m}$ mag-fura- 2 . Arrows point to the axon of the pyramidal cell, which established a contact with a dendrite of the bitufted neuron (rectangle 1). Rectangles mark four dendritic regions of the bitufted neuron, which were selected for $\mathrm{Ca}^{2+}$ imaging. Region 1 corresponds to the intersection of an axon collateral of the pyramidal cell and a branch of a basal dendrite of the bitufted cell. Scale bar, 10 $\mu \mathrm{m} . B, \mathrm{Ca}^{2+}$ transients evoked by subthreshold (left) and suprathreshold (right) EPSPs at the regions shown in $A$. Numbers refer to those in $A$. In the presynaptic pyramidal neuron a train of $15 \mathrm{APs}$ at $50 \mathrm{~Hz}$ (bars on top traces) was evoked. Postsynaptic membrane potentials are shown on the bottom (note the different time scale). The AP (right) is truncated. C, Normalized peak $\mathrm{Ca}^{2+}$ amplitudes evoked by EPSPs remaining subthreshold (top) or being suprathreshold (middle). Data represent measurements from seven synaptic contacts and 18 adjacent dendritic regions in seven cell pairs (top) and from four of the seven synaptic contacts and nine adjacent dendritic regions (middle). For comparison, the bottom graph shows normalized peak $\left[\mathrm{Ca}^{2+}\right]_{\text {i }}$ amplitudes evoked by a single backpropagating AP evoked by somatic current injection into bitufted neurons at 5 synaptic contacts of the 7 pairs, and 12 nearby dendritic regions. Amplitudes were normalized to those evoked by subthreshold EPSPs at the identified synaptic contacts (dotted lines; average $\left[\mathrm{Ca}^{2+}\right]_{\mathrm{i}}$ amplitude, $43 \pm 15 \mathrm{~nm} ; n=7$ ). Data points were fitted with Gaussians (solid lines). Amplitudes evoked by suprathreshold EPSPs (middle) and a single backpropagating AP (bottom) were normalized to mean values of EPSPs-evoked $\left[\mathrm{Ca}^{2+}\right]_{i}$ amplitudes at the synaptic contacts, respectively.

with different indicator concentrations [Kaiser et al. (2001), their Fig. 1].

\section{Mechanisms generating dendritic $\mathrm{Ca}^{2+}$ hot spots}

Several EPSPs, evoked by repetitive APs in pyramidal cells, have to summate to initiate an AP in the bitufted interneuron that then backpropagates into the basal and apical dendritic tufts. This implies that a backpropagating AP can follow EPSPs at one synaptic contact and precede them at another contact of the same connection. Coincidence of EPSPs and dendritic APs could cause a selective increase of $\mathrm{Ca}^{2+}$ influx through NMDAR channels, by briefly relieving NMDAR channels from $\mathrm{Mg}^{2+}$ block. Consequently, when the backpropagating AP precedes the EPSP, the 

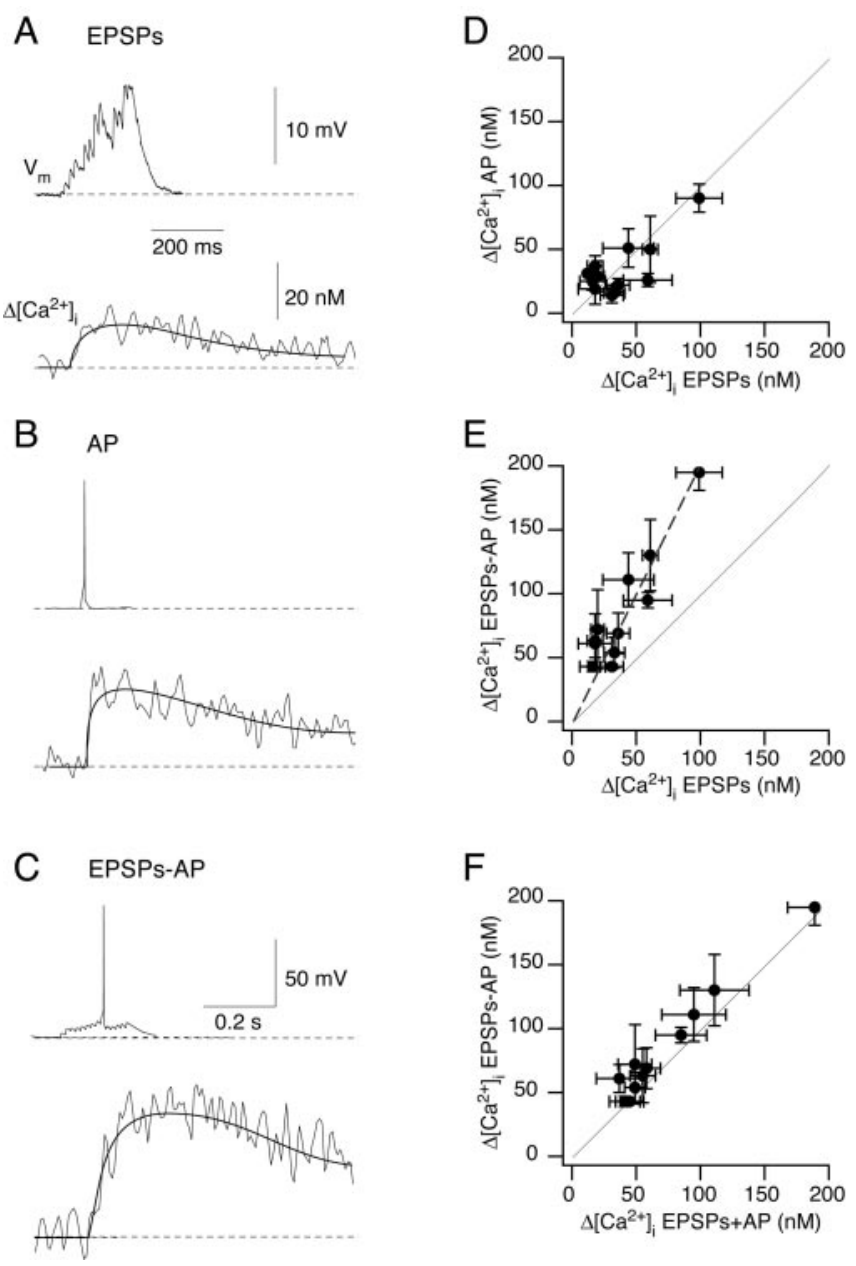

Figure 10. Summation of dendritic $\mathrm{Ca}^{2+}$ influx at single synaptic contacts. A-C, Summation of $\mathrm{Ca}^{2+}$ influx evoked by subthreshold EPSPs and by a backpropagating AP recorded at the same synaptic contact. Shown are the mean responses to subthreshold EPSPs $(A)$, to a single backpropagating AP ( $B$ ) and to suprathreshold EPSPS (EPSPs-APs) ( $C$ ). The bitufted neuron wasloaded with $250 \mu \mathrm{m}$ fura-2. The resting potential was $-59 \mathrm{mV} . D-F$, Average peak $\left[\mathrm{Ca}^{2+}\right]_{\mathrm{i}}$ amplitudes measured at identified synapses (11 pairs) in response to the different types of stimulation shown in $A-C$. In each experiment the amplitudes of $\left[\mathrm{Ca}^{2+}\right]_{i}$ transients were largest for the stimulus that evoked suprathreshold EPSPs (EPSPs-APs). The graph in Findicates that the peak $\left[\mathrm{Ca}^{2+}\right]_{\mathrm{i}}$ amplitude evoked by suprathreshold EPSPs is slightly, but significantly $(t$ test; $p<0.002$ ) larger than the arithmetic sum of $\left[\mathrm{Ca}^{2+}\right]_{\mathrm{i}}$ transients evoked by EPSPs or a single backpropagating AP alone.

$\mathrm{Ca}^{2+}$ influx through NMDAR channels may be smaller. In addition, an increase in dendritic $\mathrm{Ca}^{2+}$ induced by the AP can inhibit following $\mathrm{Ca}^{2+}$ influx through NMDARs (Ehlers et al., 1996; Medina et al., 1996). Both mechanisms may operate at the same contact during repetitive EPSPs evoked by a train of presynaptic APs. The opposing effects of near-coincident EPSPs and APs on $\mathrm{Ca}^{2+}$ influx may explain why we observed, on average, only a small supralinear summation of $\mathrm{Ca}^{2+}$ influxes when EPSPs were followed by an AP compared with the supralinearity reported for spines of pyramidal cells in cortical L5 and hippocampal CA1 (Magee and Johnston, 1997; Köster and Sakmann, 1998; Schiller et al., 1998; Yuste et al., 1999) and in spiny cells of cortical L4 (T. Nevian and B. Sakmann, unpublished observations). However, bitufted interneurons are another example of neurons in which the supralinear summation of $\mathrm{Ca}^{2+}$ signals could be part of a coincidence detection mechanism, which seems to be widespread in the CNS. Although the net effect we describe here is small because of the particular stimulation protocol used, the phenomenon presumably is important, especially when synaptic input arrives from several presynaptic pyramids and evokes suprathreshold excitation.

\section{Localized dendritic $\left[\mathrm{Ca}^{2+}\right]_{\mathrm{i}}$ transients as part of a local feedback loop}

The larger $\mathrm{Ca}^{2+}$ influx at active contacts, compared with nonsynaptic dendritic segments or at nonactive synaptic contacts, is presumably part of a local feedback mechanism that limits synaptic excitation of bitufted interneurons by pyramidal cells (Zilberter et al., 1999). Reduction of glutamate release by dendritic electrical activity is mediated by a global rise of dendritic $\left[\mathrm{Ca}^{2+}\right]_{\mathrm{i}}$ with a threshold of $\sim 50 \mathrm{nM}$ and a half-maximal effect at $\sim 264 \mathrm{nM}$ (Zilberter et al., 1999). These values suggest that the release of the putative retrograde messenger GABA is triggered by a dendritic $\mathrm{Ca}^{2+}$ sensor of moderately high affinity and possibly by effective concentrations smaller than that inferred at active zones of some presynaptic CNS terminals (Bollmann et al., 2000; Schneggenburger and Neher, 2000), although the peak of the local $\left[\mathrm{Ca}^{2+}\right]_{i}$ transient might also be substantially higher. The local volumeaveraged dendritic $\left[\mathrm{Ca}^{2+}\right]_{\mathrm{i}}$ transients evoked by subthreshold EPSPs reported here reach the threshold for triggering the release of a retrograde messenger (Zilberter et al., 1999). When EPSPs are suprathreshold, the amplitude of $\left[\mathrm{Ca}^{2+}\right]_{\mathrm{i}}$ transients is halfmaximal for inhibition. Thus, the postsynaptic $\mathrm{Ca}^{2+}$ influx via NMDAR and VDCCs could be part of a very localized signaling cascade, with GABA acting as a retrograde messenger. In support of this view, the application of baclofen, a specific $\mathrm{GABA}_{B}$ receptor agonist, reduced dendritic $\left[\mathrm{Ca}^{2+}\right]_{\mathrm{i}}$ evoked by trains of 15 EPSPs to $\sim 60 \%$ of the control ( $n=3$; data not shown), presumably by reducing glutamate release from pyramidal cell boutons.

In dendrites of pyramidal cells and spiny stellate cells the $\left[\mathrm{Ca}^{2+}\right]_{\mathrm{i}}$ transients evoked by subthreshold synaptic stimulation are almost exclusively restricted to single spines (Yuste and Denk, 1995; Köster and Sakmann, 1998) (Nevian and Sakmann, unpublished observations). In contrast, in bitufted interneurons the dendritic $\left[\mathrm{Ca}^{2+}\right]_{\mathrm{i}}$ transients extend over a relatively long segment of a dendritic branch that is almost 10-fold longer than the average diameter of a spine. It reflects the fact that the synaptic contacts between pyramidal and bitufted cells are mostly located on dendritic shafts. One functional implication could be that postsynaptic $\mathrm{Ca}^{2+}$ signals evoked by one particular connection could also affect neighboring synaptic contacts of other excitatory connections.

\section{Functional significance of facilitation and retrograde inhibition at pyramidal-to-bitufted synapses}

The exact function of $\mathrm{L} 2 / 3$ bitufted interneurons in the cortical network is not yet clear. Pyramidal-to-bitufted cell connections, however, have two characteristic properties that might suggest a specific function for these cells, at least in the somatosensory cortex. First, EPSPs in bitufted cells strongly facilitate on repetitive stimulation; second, the spread of the axonal arbor of bitufted cells is restricted in a columnar manner with only a few axon collaterals, which show long horizontal extensions (Kaiser et al., 2001). APs generated in a bitufted cell by excitation via L2/3 pyramidal cells will propagate orthodromically into the axon arbor and release GABA from boutons to inhibit L2/3 pyramidal neuron excitation. At the same time, backpropagating APs will release GABA from dendrites and reduce locally the effects of pyramidal cell excitation. During whisking behavior of rodents (at $\approx 10 \mathrm{~Hz}$ ) the center-surround structure of the cortical repre- 
sentation of a vibrissa is enhanced (Moore et al., 1999). Whisking during exploratory behavior is supposed to increase the specificity of individual whisker representations in the barrel cortex. This sharpening of the representational whisker map might be attributed to an enhanced inhibition within and between barrel columns in L2/3. When the excitation of several L2/3 pyramidal neurons within a column generates one or several APs in a common target bitufted cell, the pyramidal cell excitation will be reduced by the bitufted-to-pyramidal feedback via GABA released from bitufted cell boutons. At the same time, GABA released from bitufted cell dendrites would "buffer" the excitation of bitufted cells and thus limit the bitufted-to-pyramidal feedback inhibition.

\section{References}

Bollmann JH, Sakmann B, Borst JG (2000) Calcium sensitivity of glutamate release in a calyx-type terminal. Science 289:953-957.

Cauli B, Porter JT, Tsuzuki K, Lambolez B, Rossier J, Quenet B, Audinat E (2000) Classification of fusiform neocortical interneurons based on unsupervised clustering. Proc Natl Acad Sci USA 97:6144-6149.

Cobb SR, Buhl EH, Halasy K, Paulsen O, Somogyi P (1995) Synchronization of neuronal activity in hippocampus by individual GABAergic interneurons. Nature 378:75-78.

DeFelipe J, Farinas I (1992) The pyramidal neuron of the cerebral cortex: morphological and chemical characteristics of the synaptic inputs. Prog Neurobiol 39:563-607.

Denk W, Strickler JH, Webb WW (1990) Two-photon laser scanning fluorescence microscopy. Science 248:73-76.

Ehlers MD, Zhang S, Bernhadt JP, Huganir RL (1996) Inactivation of NMDA receptors by direct interaction of calmodulin with the NR1 subunit. Cell 84:745-755.

Goldberg JH, Yuste R, Tamas G (2003) $\mathrm{Ca}^{2+}$ imaging of mouse neocortical interneurone dendrites: contribution of $\mathrm{Ca}^{2+}$-permeable AMPA and NMDA receptors to subthreshold $\mathrm{Ca}^{2+}$ dynamics. J Physiol (Lond) 551:67-78.

Grynkiewicz G, Poenie M, Tsien RY (1985) A new generation of $\mathrm{Ca}^{2+}$ indicators with greatly improved fluorescence properties. J Biol Chem 260:3440-3450.

Jaffe DB, Fisher SA, Brown TH (1994) Confocal laser scanning microscopy reveals voltage-gated calcium signals within hippocampal dendritic spines. J Neurobiol 25:220-233.

Jones EG, Peters A (1984) Cerebral cortex, Vol 2, Functional properties of cortical cells. New York: Plenum.

Kaiser KMM, Zilberter Y, Sakmann B (2001) Back-propagating action potentials mediate calcium signalling in dendrites of bitufted interneurons in layer 2/3 of rat somatosensory cortex. J Physiol (Lond) 535:17-31.

Kamboj SK, Swanson GT, Cull-Candy SG (1995) Intracellular spermine confers rectification on rat calcium-permeable AMPA and kainate receptors. J Physiol (Lond) 486:297-303.

Kawaguchi Y (1995) Physiological subgroups of nonpyramidal cells with specific morphological characteristics in layer II/III of rat frontal cortex. J Neurosci 15:2638-2655.

Köster HJ, Sakmann B (1998) Calcium dynamics in single spines during coincident presynaptic and postsynaptic activity depend on relative timing of back-propagating action potentials and subthreshold excitatory postsynaptic potentials. Proc Natl Acad Sci USA 95:9596-9601.

Köster HJ, Sakmann B (2000) Calcium dynamics associated with action potentials in single nerve terminals of pyramidal cells in layer $2 / 3$ of the young rat neocortex. J. Physiol (Lond) 529:625-646.

Kovalchuk Y, Eilers J, Lisman J, Konnerth A (2000) NMDA receptor- mediated subthreshold $\mathrm{Ca}^{2+}$ signals in spines of hippocampal neurons. J Neurosci 20:1791-1799.

Lübke J, Egger V, Sakmann B, Feldmeyer D (2000) Columnar organization of dendrites and axons of single and synaptically coupled excitatory spiny neurons in layer 4 of the rat barrel cortex. J Neurosci 20:5300-5311.

Lübke J, Roth A, Feldmeyer D, Sakmann B (2003) Morphometric analysis of the columnar innervation domain of neurons connecting layer 4 and layer 2/3 of juvenile rat barrel cortex. Cerebral Cortex 13:1051-1063.

Magee JC, Johnston D (1997) A synaptically controlled, associative signal for Hebbian plasticity in hippocampal neurons. Science 275:209-213.

Markram H, Lübke J, Frotscher M, Roth A, Sakmann B (1997) Physiology and anatomy of synaptic connections between thick tufted pyramidal neurones in the developing rat neocortex. J Physiol (Lond) 500:409-440.

Markram H, Wang Y, Tsodyks M (1998) Differential signaling via the same axon of neocortical pyramidal neurons. Proc Natl Acad Sci USA 95:5323-5328.

Medina I, Filippova N, Bakhramov A, Bregestovski P (1996) Calciuminduced inactivation of NMDA receptor-channels evolves independently of run-down in cultured rat brain neurones. J Physiol (Lond) 495:411-427.

Moore CI, Nelson SB, Sur M (1999) Dynamics of neuronal processing in rat somatosensory cortex. Trends Neurosci 22:513-520.

Murthy VN, Sejnowski TJ, Stevens CF (2000) Dynamics of dendritic calcium transients evoked by quantal release at excitatory hippocampal synapses. Proc Natl Acad Sci USA 97:901-906.

Naraghi M, Neher E (1997) Linearized buffered $\mathrm{Ca}^{2+}$ diffusion in microdomains and its implications for calculation of $\left[\mathrm{Ca}^{2+}\right]$ at the mouth of a calcium channel. J Neurosci 17:6961-6973.

Reyes A, Lujan R, Rozov A, Burnashev N, Somogyi P, Sakmann B (1998) Target-cell-specific facilitation and depression in neocortical circuits. Nat Neurosci 1:279-285.

Rozov A, Burnashev N (1999) Polyamine-dependent facilitation of postsynaptic AMPAR receptors counteracts paired-pulse depression. Nature 401:594-598.

Rozov A, Burnashev N, Sakmann B, Neher E (2001) Transmitter release modulation by intracellular $\mathrm{Ca}^{2+}$ buffers in facilitating and depressing nerve terminals of pyramidal cells in layer $2 / 3$ of the rat neocortex indicates a target cell-specific difference in presynaptic calcium dynamics. J Physiol (Lond) 531:807-826.

Schiller J, Schiller Y, Clapham DE (1998) NMDA receptors amplify calcium influx into dendritic spines during associative presynaptic and postsynaptic activation. Nat Neurosci 1:114-118.

Schneggenburger R, Neher E (2000) Intracellular calcium dependence of transmitter release rates at a fast central synapse. Nature 406:889-893.

Schröder R, Luhmann HJ (1997) Morphology, electrophysiology and pathophysiology of supragranular neurons in rat primary somatosensory cortex. Eur J Neurosci 9:163-176.

Somogyi P, Tamas G, Lujan R, Buhl EH (1998) Salient features of synaptic organisation in the cerebral cortex. Brain Res Brain Res Rev 26:113-135.

Wollmuth LP, Kuner T, Sakmann B (1998) Adjacent asparagines in the NR2subunit of the NMDA receptor channel control the voltage-dependent block by extracellular $\mathrm{Mg}^{2+}$. J Physiol (Lond) 506:13-32.

Yuste R, Denk W (1995) Dendritic spines as basic functional units of neuronal integration. Nature 375:682-684.

Yuste R, Majewska A, Cash SS, Denk W (1999) Mechanisms of calcium influx into hippocampal spines: heterogeneity among spines, coincidence detection by NMDA receptors, and optical quantal analysis. J Neurosci 19:1976-1987.

Zilberter Y, Kaiser KMM, Sakmann B (1999) Dendritic GABA release depresses excitatory transmission between layer $2 / 3$ pyramidal and bitufted neurons in rat neocortex. Neuron 24:979-988. 